\title{
ASSOCIATIONS BETWEEN HYDROLOGICAL CONNECTIVITY AND \\ RESOURCE PARTITIONING AMONG SYMPATRIC GAR SPECIES \\ (LEPISOSTEIDAE) IN A TEXAS RIVER AND ASSOCIATED OXBOWS
}

\author{
A Thesis
}

by

\section{CLINTON RAY ROBERTSON}

\author{
Submitted to the Office of Graduate Studies of \\ Texas A\&M University \\ in partial fulfillment of the requirements for the degree of \\ MASTER OF SCIENCE
}

December 2007

Major Subject: Wildlife and Fisheries Sciences 


\section{ASSOCIATIONS BETWEEN HYDROLOGICAL CONNECTIVITY AND \\ RESOURCE PARTITIONING AMONG SYMPATRIC GAR SPECIES \\ (LEPISOSTEIDAE) IN A TEXAS RIVER AND ASSOCIATED OXBOWS}

A Thesis

by

CLINTON RAY ROBERTSON

Submitted to the Office of Graduate Studies of

Texas A\&M University

in partial fulfillment of the requirements for the degree of

\section{MASTER OF SCIENCE}

Approved by:

Chair of Committee, Kirk Winemiller

Committee Members, Stephen Davis

Georgianne Moore

Head of Department, Thomas Lacher, Jr.

December 2007

Major Subject: Wildlife and Fisheries Sciences 


\begin{abstract}
Associations Between Hydrological Connectivity and Resource Partitioning Among Sympatric Gar Species (Lepisosteidae) in a Texas River and Associated Oxbows.
\end{abstract}

(December 2007)

\author{
Clinton Ray Robertson, B.S., Texas A\&M University \\ Chair of Advisory Committee: Dr. Kirk O. Winemiller
}

The middle Brazos River, located in east central Texas, is a meandering lowland river that contains many oxbow lakes on its floodplain. Flood dynamics of the Brazos River are aseasonal, and faunal exchange during lateral connections of the main river channel and oxbows is pulse-like and only occurs during floods that may be months or years apart. Patterns of resource use among sympatric gar species (Lepisosteus oculatus, L. osseus, and Atractosteus spatula) associated with river-floodplain connectivity was studied for a period of two years (May 2003 to May 2005). The first year was relatively dry yielding few lateral connections, whereas the second year was relatively wet resulting in more frequent lateral connections. This study focused on habitat and diet partitioning among the three gar species in oxbow habitats with different connection frequencies and an active river channel site. Overall, 684 gars were collected with experimental gillnets: 19 A. spatula (alligator gar), 374 L. oculatus (spotted gar), and 
291 L. osseus (longnose gar). There was strong partitioning of habitat between spotted and longnose gars, in which $98 \%$ of spotted gars were captured in oxbow habitats and $84 \%$ of longnose gars were captured in the river channel. Hydrology did not appear to affect habitat partitioning, although longnose gar abundance significantly increased in oxbows during the wet year. Diet overlap was high between spotted and longnose gars. Temporal variation in diet was significantly influenced by flood pulses that connected oxbows with the river channel, and which allowed predators and their prey to move between habitats. 


\section{DEDICATION}

To all my family and friends, thank you for all your support and encouragement. 


\section{ACKNOWLEDGEMENTS}

I am especially thankful to my committee chair, Dr. Kirk Winemiller for all his support and patience, and to my committee members, Dr. Stephen Davis and Dr. Georgianne Moore, for their guidance and support throughout the course of this research.

I would also like to thank D. Lightsey and J.T. Lyons for granting us access to study sites. I also would like to thank all the individuals who assisted during field sampling: Steve Zeug, John Putegnat, Joe Muir, John Kirk, Mark Garza, David LaFever, David Hoeinghaus, Virginia Shrevette, Jenny Birmbaum, S. Bibiana Correa, Allison Pease, and Jenny Cochran. 


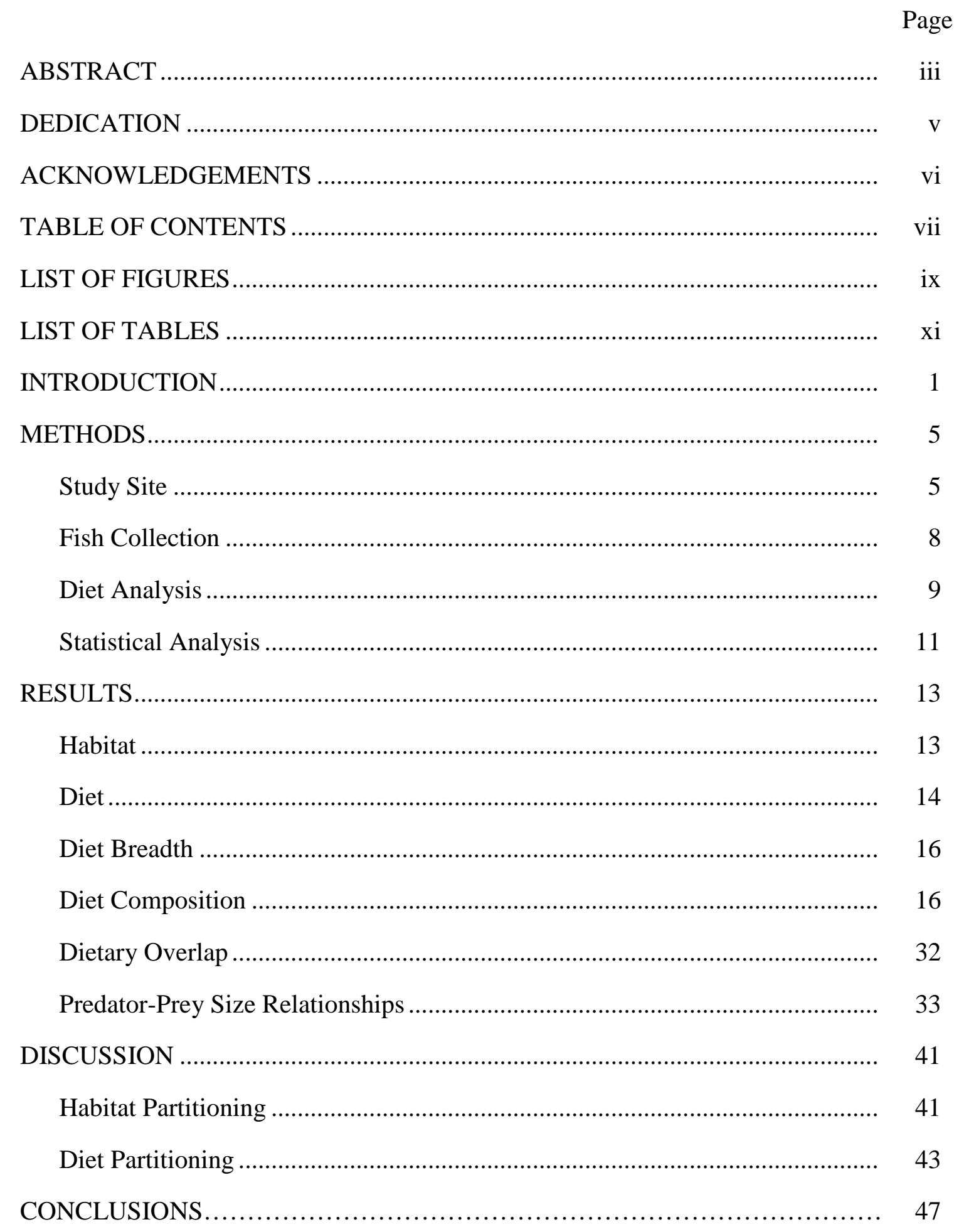




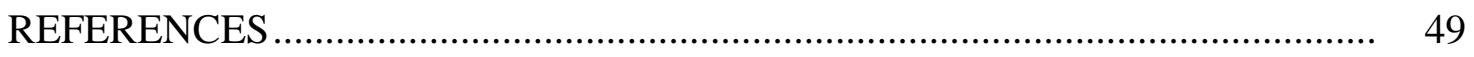

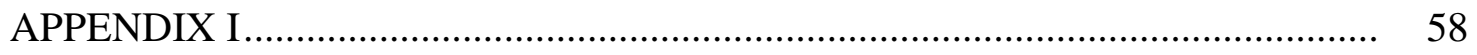

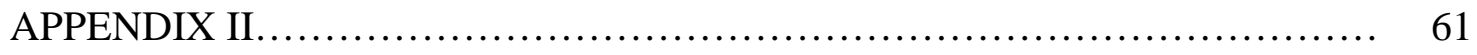

APPENDIX III.................................................... 62

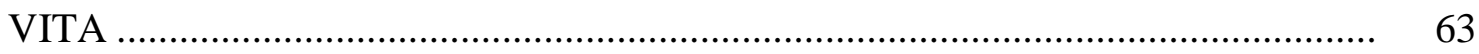




\section{LIST OF FIGURES}

Page

Figure 1 Middle Brazos River with study sites Moehlman and Big Bend oxbows.

Figure 2 Hydrograph of daily stream flow ( $\left.\mathrm{m}^{3} / \mathrm{s}[\mathrm{CMS}]\right)$ of the Brazos River at the Texas State Highway 21 bridge from June 2003 to May 2005. The lower dashed line represents river flow required to connect Big Bend oxbow, and the upper solid line represents river flows required to connect Moehlman's oxbow. Connectivity estimates provided by the Texas Water Development Board (TWDB 2004).

Figure 3 Seasonal diet breadths, based on 15 prey categories during the dry year and 20 prey categories for the wet year for L. oculatus in Moehlman's and Big Bend oxbows and L. osseus in the Brazos River.

Figure 4 PCA ordination plot based on seasonal volumetric proportions of diet items for spotted gars in Big Bend oxbow........

Figure 5 PCA ordination plot based on seasonal volumetric proportions of diet items for longnose gars in the Brazos River.......

Figure 6 Changes in abundance of shad (Clupeidae) and catfish (Ictaluridae) during the two year sampling period in the Brazos River and Moehlman's oxbow. CPUE for shad and catfish are at different scales on the Y-axis 
Figure 7 PCA ordination plot based on seasonal volumetric proportions of diet items for spotted gars in Moehlman's oxbow ....

Figure 8 Relationship between log transformed prey standard length and log transformed gar weight

$(\bigcirc=$ L. oculatus, $\square=$ L. osseus $)$. 


\section{LIST OF TABLES}

Page

Table 1 Total catch and catch per unit effort (\# per gillnet hour, CPUE) by gar species, year, and sample site.

Table 2 Total number of stomachs removed (percent empty) by species, site, and year.

Table 3 Standardized Index of Relative Importance (IRI) values as \%IRI for prey items consumed by spotted gars in Big Bend oxbow by season, year, and total for both years (TOTAL).

Table 4 Standardized Index of Relative Importance (IRI) values as \%IRI for prey items consumed by spotted gars in Moehlman's oxbow by season, year, and total for both years (TOTAL).

Table 5 Standardized Index of Relative Importance (IRI) values as $\%$ IRI for prey items consumed by longnose gars in the Brazos River by season, year, and total for both years (TOTAL)

Table 6 Standardized Electivities $\left(\mathrm{e}_{\mathrm{ij}}\right)$ values as $\% \mathrm{e}_{\mathrm{ij}}$ for prey items consumed by longnose gars in the Brazos River by season, year, and total for both years (TOTAL).

Table 7 Standardized Electivities $\left(\mathrm{e}_{\mathrm{ij}}\right)$ values as $\% \mathrm{e}_{\mathrm{ij}}$ for prey items consumed by spotted gars in Big Bend oxbow by season, year, and total for both years (TOTAL). 
Table 8 Standardized Electivities $\left(\mathrm{e}_{\mathrm{ij}}\right)$ values as $\% \mathrm{e}_{\mathrm{ij}}$ for prey items consumed by spotted gars in Moehlman's oxbow by season, year, and total for both years (TOTAL).

Table 9 Standardized Index of Relative Importance (IRI) values as \%IRI for prey items consumed by alligator gars $(n=17)$ in Big Bend and Moehlman's oxbows and total for both oxbows (TOTAL) for fish collected during the wet year.

Table 10 Standardized Electivities $\left(\mathrm{e}_{\mathrm{ij}}\right)$ values as $\% \mathrm{e}_{\mathrm{ij}}$ for prey items consumed by alligator gars $(n=17)$ at Big Bend and Moehlman's oxbow by season during the wet year, and total for both sites (TOTAL).

Table 11 PCA axis loadings and eigenvalues (each with $\mathrm{p}<0.05$ ) based on volumetric proportions of prey items according to gar species, sample site, and season

Table 12 Standardized seasonal niche overlap values between species pairs for both dry and wet years................................ 


\section{INTRODUCTION}

River-floodplain systems are some of the most ecologically complex systems linking both terrestrial and aquatic ecosystems, as well as headwater and estuarine river reaches. Globally, anthropogenic hydrologic alterations of river systems over the past decades have been severe enough to lead to changes in the terrestrial water cycle through climatic and biogeochemical changes (Vörösmarty \& Sahagian 2000). The most significant of these anthropogenic impacts on rivers is dam construction, which increased worldwide in the 1950's and 1970's with respect to previous years (Rosenberg et al. 2000). Over half of the large river systems throughout the world are affected by dams through fragmentation and altered flow regimes (Nilsson et al. 2005). In the temperate northern third of the world alone, $77 \%$ of large river systems are affected by fragmentation caused by dams (Dynesius \& Nilsson 1994), with the United States containing the largest number of dams and highest number of dams per unit land area. Dams have caused extensive and severe biological impacts, such as decreases in migratory fishes, decreases in riverine and estuarine taxa dependent on freshwater inflows, and increases in exotic species (Pringle et al. 2000). Because of the extent

This thesis follows the style of Ecology of Freshwater Fish. 
of biological and ecological damage caused by hydrological modifications, there has been an increasing realization of the need for river restoration (Buijse et al. 2002).

Restoration efforts by river management agencies, despite increasing understanding of natural system complexity of river systems, focus restoration efforts on simplistic flow policies, such as minimum flows for maintaining biological integrity of lotic systems, and often ignore biologically and ecologically important natural flow variability (Arthington et al. 2006). The best river restoration management plan would incorporate natural flow variability, but most importantly incorporate flows that allow for river-floodplain connections that are important for maintaining biological productivity and diversity in lotic systems (Galat et al. 1998), through flow magnitude, frequency, duration, timing, and rate of change, or what is known as 'The Natural Flow Regime' (Poff et al. 1997). The natural flow regime incorporates the importance of river-floodplain connections, and the variability of these connections as described by the 'Flood Pulse Concept' that was developed to describe the increased productivity and diversity of both terrestrial and aquatic zones in river-floodplain systems through natural flow variability (Bayley 1991, Bayley 1995, Junk et al. 1989, Junk 1999, Tockner et al. 2000). Flood pulses not only increase productivity within river-floodplain systems, but the flood pulse itself allows for fish movements between river and floodplain habitats to exploit and transport productivity between habitats (Hohausova 2000, Kwak 1988, Ross \& Baker 1983, Thomaz et al. 2007, Winemiller et al. 1996, Zeug et al. 2005). These fish movements afford piscivores the opportunity to move between river-floodplain habitats 
to forage on abundant prey, or to consume prey as they move between the habitats (Balcombe et al. 2005, O'Connell 2003).

The middle Brazos River, located in east-central Texas, maintains an active riverfloodplain connection through stochastic flood events, allowing fishes the opportunity to move between river and habitats, such as oxbow lakes, located on its floodplain. Of particular importance are three sympatric predatory piscivores from the family Lepisosteidae (alligator gar-Atractosteus spatula, longnose gar - Lepisosteus osseus, spotted gar - Lepisosteus oculatus). These common native fishes potentially can use floodplain habitats and/or resources during periods of hydrologic connection. Due to their high abundance and potential for top-down control of fish populations, these fishes play an important role in the ecology of the middle Brazos River. Therefore, it is essential to understand the influence of river-floodplain connections on resource utilization by these species.

Despite their unique morphological characteristics, ancient origins, and broad distributions in North America, fishes in the order Lepisosteiformes have received relatively little attention in the ecological literature. The seven living gar species of the family Lepisosteidae are found in North America, Central America and Cuba (Helfman et al. 1999). Most studies on the ecology of this ancient lineage of fishes have focused on the impact of gars on recreationally important species, by either directly consuming them or competing with them for prey (Lagler and Hubbs 1940, Bonham 1941, Lagler $e t$ al. 1942, Crumpton 1971). The paucity of ecological research on gars may be associated 
with their history of classification as "rough" or "trash" fish by many natural resource agencies.

Here I investigate resource use among the three sympatric gar species in the Middle Brazos River during a year with relatively few river-oxbow connections and a year with frequent river-oxbow connections. For this study I compared both habitat use (oxbow vs. river channel) and diet during periods of isolation and following periods of flood connection for all three gar species. I hypothesize that the gar species will either partition food resources or habitats in order to reduce competition between species. For example, different gar species could co-occur in the same habitat if they partition food resources, or different gar species could partition habitats and consume similar prey resources. I also hypothesize that flood connections are important for structuring the habitat partitioning and diet of gars in both oxbow and river habitats. For example, river-floodplain connections could allow an increase in prey available for gars in the river channel given the highly productive and abundant fish communities found within oxbow habitats, and would allow gar in the river to move into oxbow habitats. These connection events are also important for maintaining oxbow fish communities, given the propensity for oxbow to desiccate during periods of isolation, thus are important for maintaining prey resources for gars within oxbows and allowing them to move from oxbow habitats into the river channel during connections. 


\section{METHODS}

Study Site

The Brazos River originates in northwest Texas, and flows southeast across the state entering the Gulf of Mexico near Freeport, Texas. Our study focused on the middle Brazos River (between $30^{\circ} 25^{\prime} \mathrm{N}$ and $30^{\circ} 37^{\prime} \mathrm{N}$ ), a meandering lowland reach with a broad floodplain dominated by forest and agricultural lands (Figure 1). Aerial surveys identified more than 40 oxbow lakes on the floodplain of the middle Brazos River (Winemiller et al. 2000). Sampling was conducted monthly from June 2003 to May 2005 at two oxbows (Big Bend and Moehlman's) and the Brazos River channel at the Texas State Highway 21 bridge. For more detailed descriptions of the study sites, refer to Winemiller et al. (2000) and Zeug et al. (2005).

Big Bend and Moehlman's oxbows differ geomorphologically (Winemiller et al. 2000). Big Bend oxbow is located closer to the active channel than Moehlman's oxbow, and lower flows are required to connect Big Bend oxbow with the river channel (Zeug et al. 2005). Figure 2 shows the daily stream flow hydrograph during the 2 -yr study period. The first year of the study was relatively dry with few connection events (dry year). In the second year, river-oxbow connection events were relativly frequent (wet year), yielding multiple connections of Moehlman's oxbow which, on average, connects with the river channel only once every 1.93 years (unpublished data). 


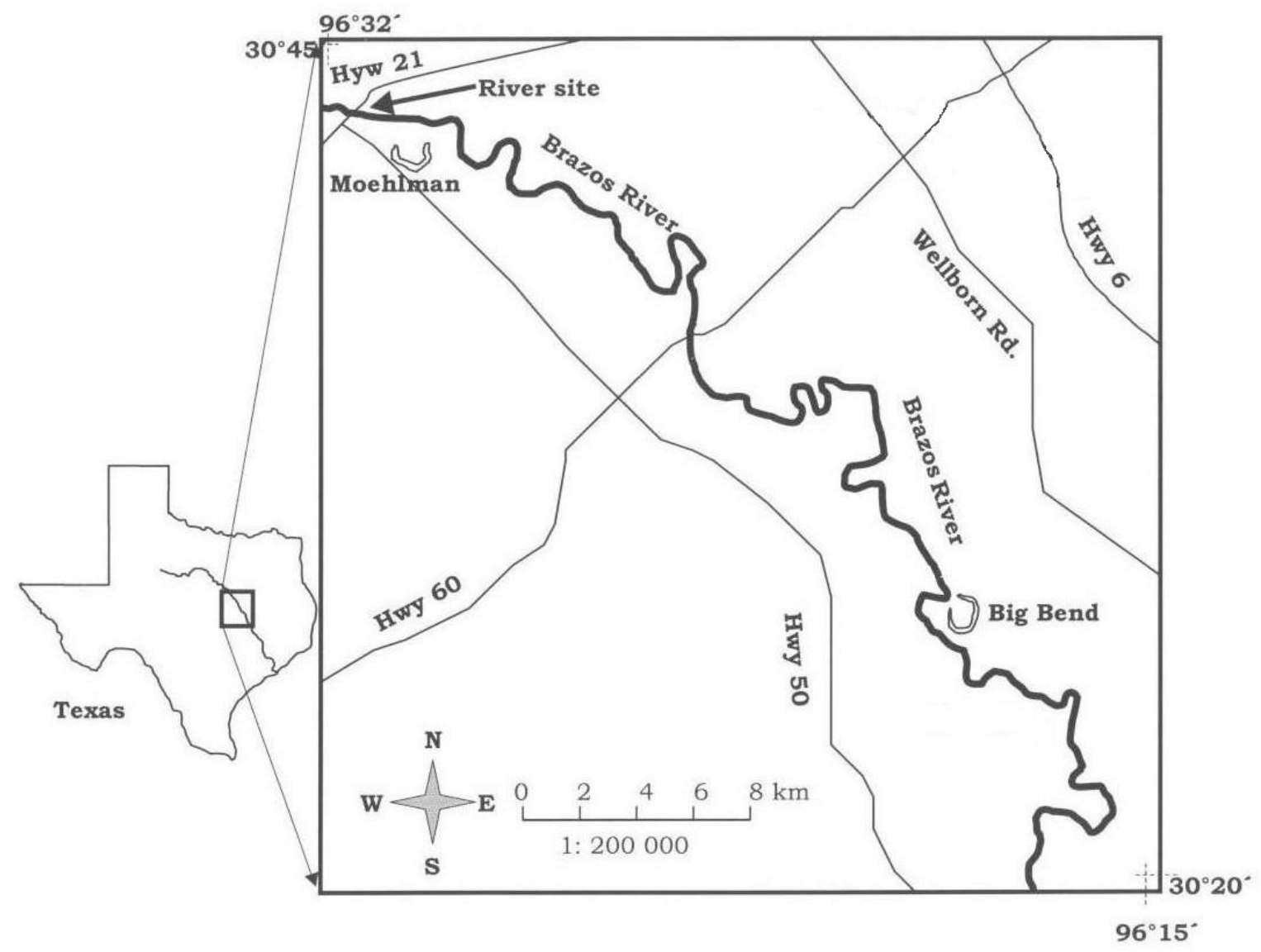

Figure 1. Middle Brazos River with study sites Moehlman and Big Bend oxbows. 


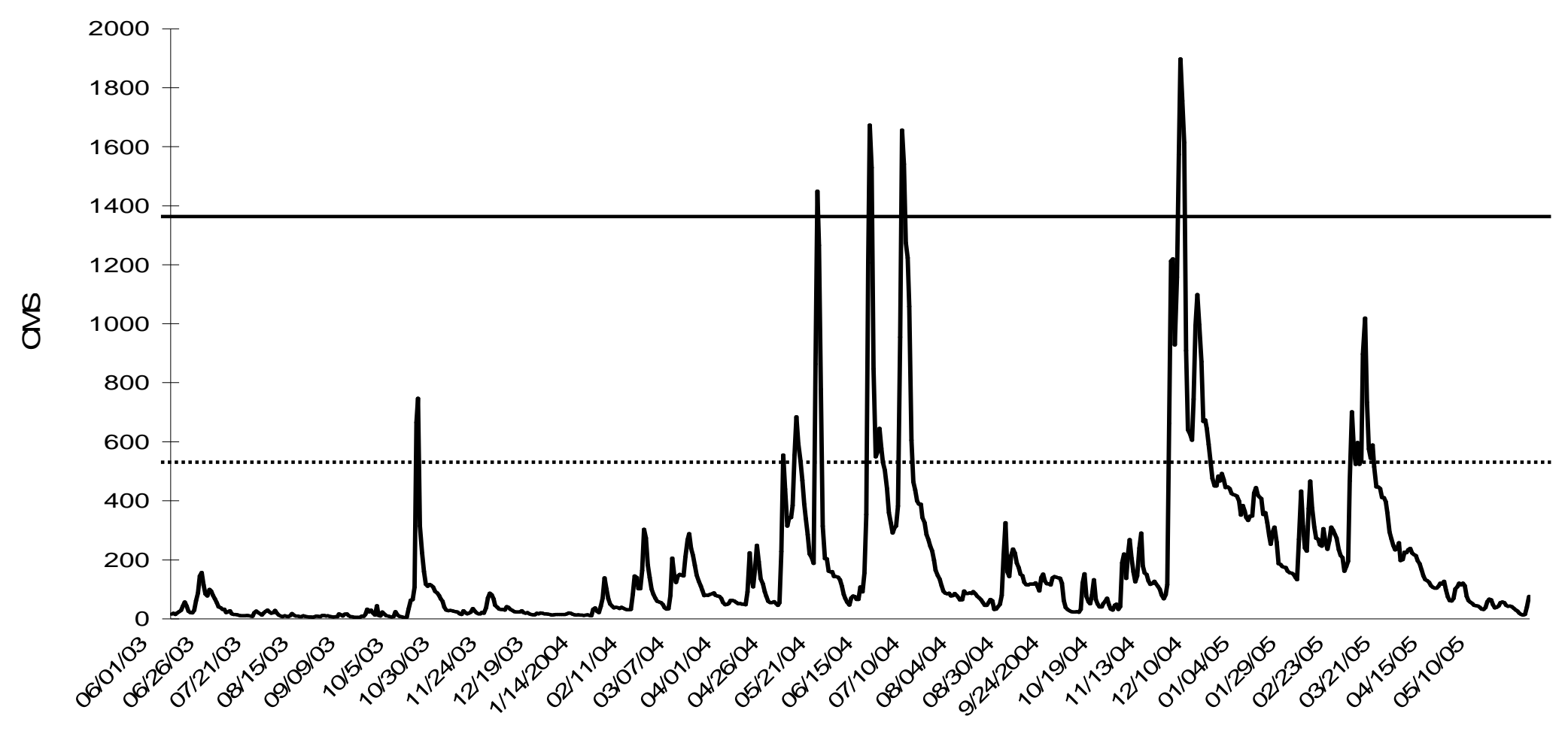

Figure 2. Hydrograph of daily stream flow $\left(\mathrm{m}^{3} / \mathrm{s}[\mathrm{CMS}]\right)$ of the Brazos River at the Texas State Highway 21 bridge from June 2003 to May 2005. The lower dashed line represents river flow required to connect Big Bend oxbow, and the upper solid line represents river flows required to connect Moehlman's oxbow. Connectivity estimates provided by the Texas Water Development Board (TWDB 2004). 
Fish Collection

Gars were collected using experimental multifilament gillnets consisting of three $16.5 \mathrm{~m}$ x $2 \mathrm{~m}$ panels of 2.54-, 5.1-, and 7.6-cm bar mesh. Gillnets were set from approximatly $1600 \mathrm{~h}$ to $800 \mathrm{~h}$ the next day. The duration of each gillnet set was recorded for calculations of catch-per-unit effort (CPUE). Gars captured in gillnets were transported to the laboratory on ice, measured to the nearest $0.1-\mathrm{cm}$ standard length (SL), and weighed to the nearest gram. Stomachs were removed and fixed in a $10 \%$ formalin solution. Some studies have indicated that piscivores may regurgitate stomach contents when captured using gillnets (e.g. Sutton et al. 2004), but little

evidence of regurgitation (few fully distended but empty stomachs) was encountered during this study.

To estimate prey abundance, small fishes and grass shrimp (Palaemonidae) were collected during each survey using a $10 \mathrm{~m}$ x $2 \mathrm{~m}$ bag seine with $0.64-\mathrm{cm}$ mesh in the wings and $0.32-\mathrm{cm}$ mesh in the bag, following Winemiller et al. 2000. The seine was hauled perpendicular to shore at different locations until three consecutive hauls yielded no additional species to the cumulative list. The distance of each seine haul was estimated for calculations of prey species CPUE. Fish and grass shrimpcollected in the seine were preserved in $10 \%$ formalin and returned to the laboratory where they were identified to species, counted, and weighed to the nearest $0.1 \mathrm{~g}$. Based on comparisons with data from electrofishing and experimental gillnetting, seining was determined to be a highly effective method of surveying fish assemblages in oxbow lakes (Winemiller $e t$ 
al. 2000). Oxbows were uniformally shallow $(0.5-2 \mathrm{~m})$, and the $10 \mathrm{~m} \times 2 \mathrm{~m}$ seine efficiently captured small and intermediate size classes of all fish species that were the principal prey of gar.

Diet Analysis

Fishes were identified to the lowest possible taxonomic level, and invertebrates were identified to order. Each prey item was counted, measured (SL for fishes and total length for all other prey items) to the nearest $1 \mathrm{~mm}$, and its volume determined by water displacement (Winemiller \& Pianka 1990) to the nearest $0.01 \mathrm{ml}$. For analysis, prey items were grouped by family for fish and order for invertebrates. Resource categories that consisted of unidentified or miscellaneous fish were not included in the calculation of indices. Diets were compared among gar species between seasons and years. Seasonal groupings were designated as summer (June-August), fall (SeptemberNovember), winter (December-February), and spring (March-May).

Diet overlap was estimated with Pianka's (1974) symmetrical niche overlap:

$$
\phi_{j k}=\frac{\Sigma p_{i j} p_{i k}}{\sqrt{\Sigma p_{i j}{ }^{2} \Sigma p_{i k}^{2}}}
$$

where $\mathrm{p}_{i j}$ and $\mathrm{p}_{i k}$ represent the volumetric proportion of prey category $i$ in the diet of consumer species $j$ and $k$. Values for this symmetrical overlap index range from zero, 
which indicates no overlap in diet, to 1 , indicating an identical diet or complete overlap between consumer species $j$ and $k$, respectively.

Resource preferences were calculated using Lawlor's (1980) electivities $\left(e_{i j}\right)$. For each consumer species $j$, electivities were calculated for each prey category $i$ as:

$$
e_{i j}=\frac{p_{i j}}{R_{i}}
$$

where $\mathrm{p}_{i j}$ is the volumetric proportion of prey category $i$ in the diet of consumer species $j$, and $\mathrm{R}_{i}$ is the relative proportion of prey species (fish and grass shrimp) $i$ in the habitat (seine samples). In order to make comparisons, all electivities were standardized as a percentage of the totals.

An Index of Relative Importance (IRI) (Pinkas et al. 1971) also was calculated for each prey category $i$ found in the diet of each consumer species $j$ :

$$
\mathrm{IRI}_{i j}=(\% \text { by number }+\% \text { by volume }) \times \% \text { frequency of occurrence }
$$

As with the electivities, in order to make comparisons between seasons, sites and species, the IRI's were standardized as percent IRI.

Niche breadth $\left(\mathrm{B}_{j}\right)$ for each consumer species $j$ was calculated using Levins's (1968) measure:

$$
B_{j}=\frac{1}{\sum p_{i j}^{2}}
$$


where $\mathrm{p}_{i j}$ is the volumetric fraction of prey item $i$ in the total diet of consumer species $j$. Values of $\mathrm{B}_{j}$ range from 1, indicating a minimum niche breadth or maximum specialization, to $n$, where $n$ is equal to the total number of resource states (or prey categories) indicating a maximum niche breadth and minimum specialization. For this study, there was a total of 20 prey categories (Appendix I). Niche breadth was standardized in order to make comparisons between species and habitat using Hurlbert's (1978) method:

$$
B_{A}=\frac{B_{j}-1}{n-1}
$$

where $\mathrm{B}_{\mathrm{A}}$ is Levins's standardized niche breadth for consumer species $j$, with values ranging from 0 to 1 , indicating minimum and maximum niche breadth, respectively.

To assess resource partitioning by prey size, predator weight $(\mathrm{g})$ and prey SL (mm) were log transformed and plotted against each other. Predator weight was used since spotted gars and longnose gars differ in morphology. Linear regression was used to determine the relationship between gar weight and prey standard length.

\section{Statistical Analysis}

Chi-square tests were calculated to test for significant $(\alpha<0.05)$ differences in gar abundance in river and oxbow habitats between years, as well as for differences between average gar standard lengths across habitats. Principal components analysis 
(PCA) was performed on matrices of volumetric proportions of prey items according to species, sites and seasons using CANOCO (version 4; Microcomputer Power). 


\section{RESULTS}

\section{Habitat}

During the two year study, a total of 693 gars was collected in gillnets. In the dry year, 411 gars were collected, and 282 gars were collected during the wet year. Gar CPUE was greater in the Brazos River and Moehlman's oxbow than Big Bend oxbow (Table 1). Overall, $89.4 \%$ of alligator gars and $98.1 \%$ of spotted gars were captured from oxbow habitats (Table 1). In contrast, $84.3 \%$ of longnose gars were collected from the river channel.

Distributions of spotted gar captures did not vary much between years. During the dry year, $98.7 \%$ of spotted gars were collected in oxbows and only three individuals were collected from the river channel (Table 1). During the wet year, $96.9 \%$ of spotted gars were collected from oxbows, and four individuals were collected from the river channel. Spotted gar abundance in oxbows significantly decreased during the wet year $\left(\chi^{2}=315.1, \mathrm{df}=1, \mathrm{p}<0.001\right)$. During the dry year, $97.0 \%$ of longnose gars were collected from the river channel, and only five individuals were collected from oxbow habitats. Captures of longnose gars from oxbow habitats significantly increased from $3.0 \%$ during the dry year, to $31.1 \%$ during the wet year $\left(\chi^{2}=442.3\right.$, df $\left.=1, \mathrm{p}<0.001\right)$. Longnose gar abundance in the river channel was not significantly different between years $\left(\chi^{2}=1.1, \mathrm{df}=1, \mathrm{p}=0.29\right)$. During the dry year, only two alligator gars were collected, one from an oxbow (Big Bend) and one from the river channel. During the 
wet year, 17 alligator gars were collected, with $94.1 \%$ captured in oxbows, and only one individual was captured from the river channel. Alligator gar abundance was significantly greater in oxbows during the wet year $\left(\chi^{2}=202.5, \mathrm{df}=1, \mathrm{p}<0.001\right)$. All alligator gars captured from oxbows were juveniles that ranged in size from $409-810$ $\mathrm{mm}$, whereas both of the alligator gars captured in the river channel were adults (1474 $\mathrm{mm}$ and $1850 \mathrm{~mm})$.

Diet

From the 693 gars collected, 652 stomachs were removed for analysis (Table 2). Gars in both Big Bend and Moehlman's oxbows had a low occurrence of empty stomachs (37.9\% and $37.5 \%$ respectively), whereas gars in the river channel had a high occurrence of empty stomachs (59.0\%). Between species, longnose gar had the highest occurrence of empty stomachs and spotted gar had the lowest occurrence of empty stomachs (Table 2). 
Table 1. Total catch and catch per unit effort (\# per gillnet hour, CPUE) by gar species, year, and sample site.

\begin{tabular}{|c|c|c|c|c|c|}
\hline & & A. spatula & L. oculatus & L. osseus & Total CPUE \\
\hline \multirow{3}{*}{ Dry Year } & Brazos River & $1(50.0 \%)$ & $3(1.2 \%)$ & $161(97.0 \%)$ & 0.42 \\
\hline & Big Bend & $1(50.0 \%)$ & $65(26.7 \%)$ & $3(1.8 \%)$ & 0.25 \\
\hline & Moehlman's & -- & $175(72.0 \%)$ & $2(1.2 \%)$ & 0.44 \\
\hline \multirow{3}{*}{ Wet Year } & Brazos River & $1(5.9 \%)$ & $4(3.1 \%)$ & $93(68.9 \%)$ & 0.44 \\
\hline & Big Bend & $9(52.9 \%)$ & $45(34.6 \%)$ & $23(17.0 \%)$ & 0.22 \\
\hline & Moehlman's & $7(41.2 \%)$ & $81(62.3 \%)$ & $19(14.1 \%)$ & 0.31 \\
\hline
\end{tabular}




\section{Diet Breadth}

Gar diet breadth was highly variable between sites and years (Figure 3). During the dry years, longnose gars in the river channel had higher diet breadth than spotted gars in oxbows, but longnose gars had lower diet breadth than spotted gars during the wet year. Spotted gars in Big Bend oxbow had higher diet breadth than those in Moehlman's. Spotted gar diet breadth in both oxbows increased during the spring of the dry year which coincided with over-bank flooding of both habitats (Figure 2). During the fall and winter of the dry year when Big Bend oxbow was drying out and fish abundances had declined, spotted gars in that habitat consumed only crayfish (Cambaridae). Spotted gars in Moehlman's oxbow consumed only shad (Clupeidae) during the winter of both the dry and wet years.

\section{Diet Composition}

Overall, shad and sunfish (Centrarchidae) were the most important prey items for spotted gars in oxbow habitats (Tables 3 \& 4), whereas mayflies (Ephemeroptera) and catfish (Ictaluridae) were the most important prey items for longnose gars in the river channel (Table 5). Based on electivities, catfish were the most selected prey item for longnose gars in the river channel (67.3\%, Table 6) followed by sunfish and shad.

Similarly, spotted gars in oxbow habitats also highly selected for catfish $(81.0 \%$, Tables 7 \& 8) followed by shad and sunfish. For spotted gars in Big Bend oxbow, crayfish 
$(27.7 \%)$ were the most important prey item, and shad were the most important prey item for spotted gars in Moehlman's oxbow. Sunfish were also important prey for spotted gars in both oxbows (Big Bend - 22.3\%, Moehlman's - 16.5\%). Based on a limited sample size collected during the wet year, shad (37.5\%) and suckers (Catastomidae, $31.7 \%$ ) were the most important prey for alligator gars (Table 9), were as suckers and other gars (Lepisosteidae) were strongly and positively selected for based on electivity values (Table 10).

Variation in the relative importance of other prey taxa in gar diets also was observed between habitats and years. During the wet year, shad were the most important prey, followed by catfish and minnows (Cyprinidae), for longnose gars in the river channel (Table 5). During the dry year, mayflies and catfish were the most important prey items for longnose gars, while shad importance decreased. Crayfish and sunfish were the most important prey items for spotted gars in Big Bend oxbow during the dry year, but during the wet year, shad and grasshoppers (Orthoptera) increased in importance along with catfish (Table 3). For spotted gars in Moehlman's oxbow (Table 4), sunfish and catfish importance increased during the second (wet) year, whereas shad importance decreased. 
Table 2. Total number of stomachs removed (percent empty) by species, site, and year.

\begin{tabular}{lcccc}
\hline & & Dry Year & Wet Year & Total \\
\cline { 3 - 5 } Lepisosteus oculatus & Brazos River & $3(66.7 \%)$ & $4(50.0 \%)$ & $7(57.1 \%)$ \\
& Big Bend & $65(23.1 \%)$ & $45(37.8 \%)$ & $109(29.4 \%)$ \\
& Moehlman's & $176(22.7 \%)$ & $81(34.6 \%)$ & $257(26.5 \%)$ \\
& Brazos River & $151(57.0 \%)$ & $93(68.8 \%)$ & $244(61.5 \%)$ \\
Lepisosteus osseus & Big Bend & $3(66.7 \%)$ & $23(30.4 \%)$ & $26(34.6 \%)$ \\
& Moehlman's & $2(50.0 \%)$ & $19(42.1 \%)$ & $21(42.9 \%)$ \\
& & & & \\
Atractosteus spatula & Brazos River & $1(0.0 \%)$ & $1(100 \%)$ & $2(50.0 \%)$ \\
& Big Bend & $1(100 \%)$ & $9(44.4 \%)$ & $10(50.0 \%)$ \\
& Moehlman's & -- & $7(42.9 \%)$ & $7(42.9 \%)$ \\
\hline
\end{tabular}




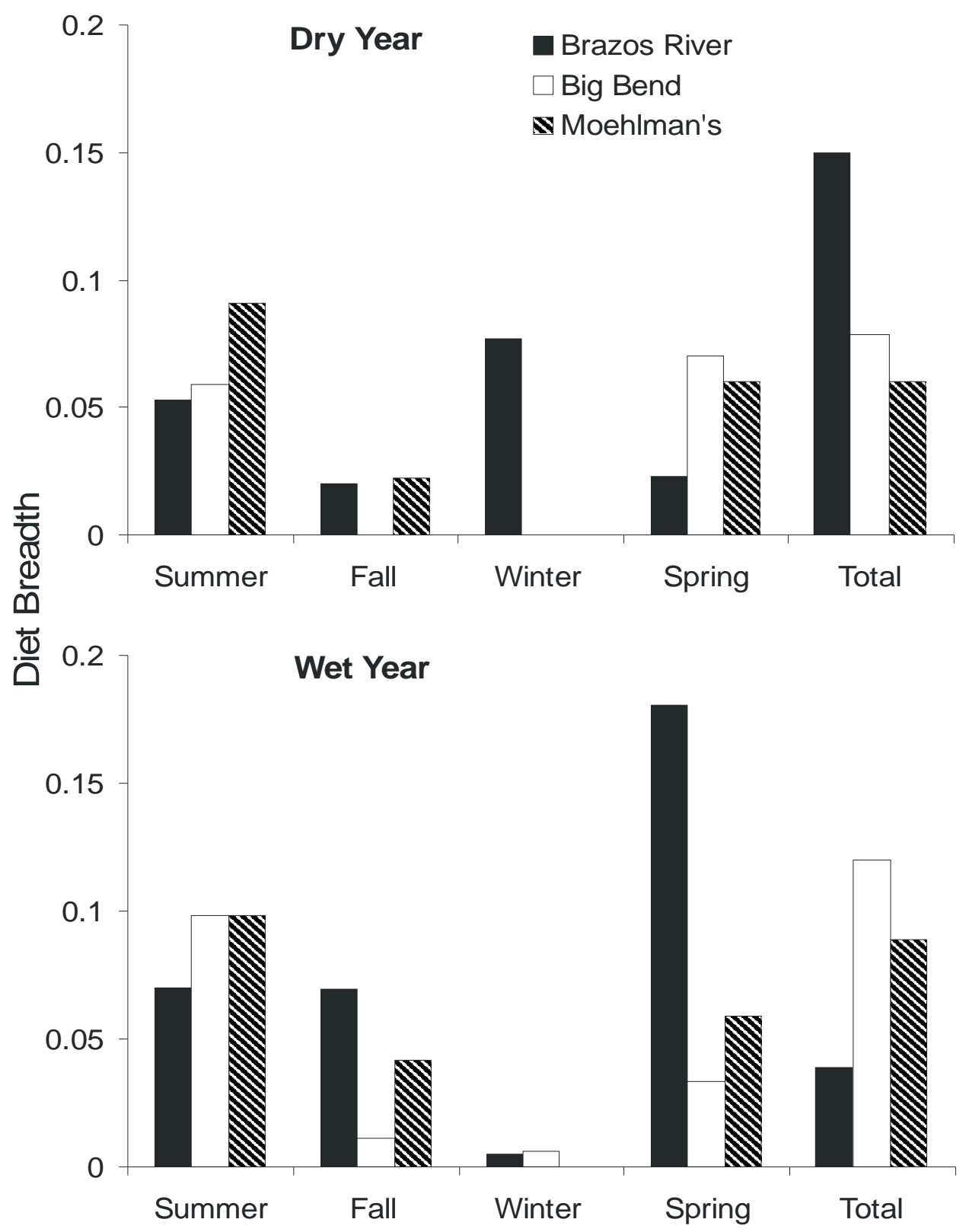

Figure 3. Seasonal diet breadths, based on 15 prey categories during the dry year and 20 prey categories for the wet year for L. oculatus in Moehlman's and Big Bend oxbows and L. osseus in the Brazos River. 
Table 3. Standardized Index of Relative Importance (IRI) values as \%IRI for prey items consumed by spotted gars in Big Bend oxbow by season, year, and total for both years (TOTAL).

\begin{tabular}{|c|c|c|c|c|c|c|c|c|c|c|c|c|c|c|c|}
\hline & \multicolumn{5}{|c|}{ Dry Year } & \multicolumn{5}{|c|}{ Wet Year } & \multicolumn{5}{|c|}{ TOTAL } \\
\hline & SUM & FAL & WIN & SPR & TOTAL & SUM & FAL & WIN & SPR & TOTAL & SUM & FAL & WIN & SPR & TOTAL \\
\hline Amphibia & -- & -- & -- & -- & -- & -- & -- & -- & -- & -- & -- & -- & -- & -- & -- \\
\hline Atherinidae & -- & -- & -- & - & -- & -- & -- & -- & - & -- & -- & - & -- & -- & -- \\
\hline Catastomidae & -- & -- & -- & -- & -- & -- & -- & -- & -- & -- & -- & -- & -- & -- & -- \\
\hline Centrarchidae & 39.2 & -- & -- & 35.4 & 30.7 & -- & 16.4 & -- & 62.0 & 10.5 & 13.6 & 12.5 & -- & 38.0 & 22.3 \\
\hline Clupeidae & 48.5 & -- & -- & -- & 15.6 & 13.2 & 76.4 & 80.7 & -- & 32.2 & 27.2 & 61.7 & 45.4 & -- & 21.0 \\
\hline Cyprinidae & 2.7 & -- & -- & -- & 1.0 & -- & -- & -- & -- & -- & 1.0 & -- & -- & -- & 0.5 \\
\hline Decapoda Cambaridae & -- & 100 & 100 & 55.0 & 42.4 & 2.3 & -- & 19.3 & 38.0 & 6.1 & 1.5 & 20.5 & 54.6 & 53.3 & 27.7 \\
\hline Diptera Tipulidae & 1.9 & -- & -- & -- & 0.9 & -- & -- & -- & -- & -- & 0.8 & -- & -- & -- & 0.5 \\
\hline Ephemeroptera & -- & -- & -- & -- & -- & -- & -- & -- & -- & -- & -- & -- & -- & -- & -- \\
\hline Hymenoptera & -- & -- & -- & -- & -- & -- & -- & -- & -- & -- & -- & -- & -- & -- & -- \\
\hline Ictaluridae & -- & -- & - & 7.1 & 4.8 & -- & -- & -- & -- & -- & 14.9 & 5.3 & -- & 6.4 & 8.8 \\
\hline Lepidoptera & -- & -- & -- & -- & -- & -- & -- & -- & -- & -- & -- & -- & -- & -- & -- \\
\hline Lepisosteidae & -- & -- & -- & -- & -- & -- & -- & -- & -- & -- & -- & -- & -- & -- & -- \\
\hline Macrobranchium & -- & -- & -- & -- & -- & -- & -- & -- & -- & -- & -- & -- & -- & -- & -- \\
\hline
\end{tabular}


Table 3. Continued

\begin{tabular}{|c|c|c|c|c|c|c|c|c|c|c|c|c|c|c|c|}
\hline & \multicolumn{5}{|c|}{ Dry Year } & \multicolumn{5}{|c|}{ Wet Year } & \multicolumn{5}{|c|}{ TOTAL } \\
\hline & SUM & FAL & WIN & SPR & TOTAL & SUM & FAL & WIN & SPR & TOTAL & SUM & FAL & WIN & SPR & TOTAL \\
\hline Odonata & -- & -- & -- & -- & -- & -- & -- & -- & -- & -- & -- & -- & -- & -- & -- \\
\hline Orthoptera & 1.9 & -- & -- & -- & 0.9 & 61.1 & -- & -- & -- & 37.4 & 38.4 & -- & -- & -- & 17.1 \\
\hline Palaemonidae & 5.9 & -- & -- & -- & 2.7 & -- & -- & -- & -- & -- & 2.5 & -- & -- & -- & 1.5 \\
\hline Percidae & -- & -- & -- & -- & -- & -- & -- & -- & -- & -- & -- & -- & -- & -- & -- \\
\hline Poecilidae & -- & -- & -- & 2.5 & 1.0 & -- & -- & -- & -- & -- & -- & -- & -- & 2.3 & 0.5 \\
\hline Rodentia & -- & -- & -- & -- & -- & -- & -- & -- & -- & -- & -- & -- & -- & -- & -- \\
\hline
\end{tabular}


Table 4. Standardized Index of Relative Importance (IRI) values as \%IRI for prey items consumed by spotted gars in Moehlman's oxbow by season, year, and total for both years (TOTAL).

\begin{tabular}{|c|c|c|c|c|c|c|c|c|c|c|c|c|c|c|c|}
\hline & \multicolumn{5}{|c|}{ Dry Year } & \multicolumn{5}{|c|}{ Wet Year } & \multicolumn{5}{|c|}{ TOTAL } \\
\hline & SUM & FAL & WIN & SPR & TOTAL & SUM & FAL & WIN & SPR & TOTAL & SUM & FAL & WIN & SPR & TOTAL \\
\hline Amphibia & -- & -- & -- & -- & -- & -- & -- & -- & -- & -- & -- & -- & -- & -- & -- \\
\hline Atherinidae & -- & -- & -- & -- & -- & -- & -- & -- & -- & -- & -- & -- & -- & -- & -- \\
\hline Catastomidae & 4.3 & 3.7 & -- & -- & 3.6 & -- & -- & -- & -- & -- & 3.0 & 2.4 & -- & -- & 2.2 \\
\hline Centrarchidae & 14.1 & 3.8 & -- & -- & 8.8 & 39.3 & 22.1 & -- & 46.5 & 28.6 & 22.2 & 10.2 & -- & 19.4 & 16.5 \\
\hline Clupeidae & 66.2 & 87.3 & 100 & 56.9 & 74.6 & 37.2 & 77.9 & 100 & 37.7 & 58.0 & 56.2 & 84.0 & 100 & 48.1 & 68.1 \\
\hline Cyprinidae & 11.0 & -- & -- & 26.0 & 7.6 & -- & -- & -- & -- & -- & 6.1 & -- & -- & 15.9 & 4.3 \\
\hline $\begin{array}{l}\text { Decapoda } \\
\text { Cambaridae }\end{array}$ & 3.4 & 5.3 & -- & 9.5 & 4.4 & -- & -- & -- & -- & -- & 2.3 & 3.4 & -- & 5.1 & 2.7 \\
\hline Diptera Tipulidae & -- & -- & -- & -- & -- & -- & -- & -- & -- & -- & -- & -- & -- & -- & -- \\
\hline Ephemeroptera & -- & -- & -- & -- & -- & -- & -- & -- & -- & -- & -- & -- & -- & -- & -- \\
\hline Hymenoptera & -- & -- & -- & -- & -- & -- & -- & -- & -- & -- & -- & -- & -- & -- & -- \\
\hline Ictaluridae & -- & -- & -- & -- & -- & 23.6 & -- & -- & -- & 11.3 & 9.4 & -- & -- & -- & 4.9 \\
\hline Lepidoptera & -- & -- & -- & -- & -- & -- & -- & -- & -- & -- & -- & -- & -- & -- & -- \\
\hline Lepisosteidae & -- & -- & -- & -- & -- & -- & -- & -- & -- & -- & -- & -- & -- & -- & -- \\
\hline Macrobranchium & -- & -- & -- & -- & -- & -- & -- & -- & -- & -- & -- & -- & -- & - & -- \\
\hline
\end{tabular}


Table 4. Continued

\begin{tabular}{|c|c|c|c|c|c|c|c|c|c|c|c|c|c|c|c|}
\hline & \multicolumn{5}{|c|}{ Dry Year } & \multicolumn{5}{|c|}{ Wet Year } & \multicolumn{5}{|c|}{ TOTAL } \\
\hline & SUM & FAL & WIN & SPR & TOTAL & SUM & FAL & WIN & SPR & TOTAL & SUM & FAL & WIN & SPR & TOTAL \\
\hline Odonata & -- & -- & -- & -- & -- & -- & -- & -- & -- & -- & -- & -- & -- & -- & -- \\
\hline Orthoptera & 1.0 & -- & -- & -- & 0.5 & -- & -- & -- & -- & -- & 0.8 & -- & -- & -- & 0.3 \\
\hline Palaemonidae & -- & -- & -- & 7.6 & 0.5 & -- & -- & -- & 15.8 & 2.1 & -- & -- & -- & 11.5 & 0.9 \\
\hline Percidae & -- & -- & -- & -- & -- & -- & -- & -- & -- & -- & -- & -- & -- & -- & -- \\
\hline Poecilidae & -- & -- & -- & -- & -- & -- & -- & -- & -- & -- & -- & -- & -- & -- & -- \\
\hline Rodentia & -- & -- & -- & -- & -- & -- & -- & -- & -- & -- & -- & -- & -- & -- & -- \\
\hline
\end{tabular}


Table 5. Standardized Index of Relative Importance (IRI) values as \%IRI for prey items consumed by longnose gars in the Brazos River by season, year, and total for both years (TOTAL).

\begin{tabular}{|c|c|c|c|c|c|c|c|c|c|c|c|c|c|c|c|}
\hline & \multicolumn{5}{|c|}{ Dry Year } & \multicolumn{5}{|c|}{ Wet Year } & \multicolumn{5}{|c|}{ TOTAL } \\
\hline & SUM & FAL & WIN & SPR & TOTAL & SUM & FAL & WIN & SPR & TOTAL & SUM & FAL & WIN & SPR & TOTAL \\
\hline Amphibia & -- & 14.2 & -- & -- & 1.8 & -- & -- & -- & -- & -- & -- & 6.6 & -- & -- & 0.7 \\
\hline Atherinidae & -- & 13.8 & -- & -- & 1.7 & -- & -- & -- & -- & -- & -- & 6.2 & -- & -- & 0.6 \\
\hline Catastomidae & -- & -- & 21.1 & -- & 6.6 & -- & -- & -- & -- & -- & -- & -- & 16.0 & -- & 4.9 \\
\hline Centrarchidae & -- & -- & 44.6 & -- & 14.3 & -- & -- & -- & -- & -- & -- & -- & 34.0 & -- & 10.6 \\
\hline Clupeidae & -- & 54.3 & -- & 46.4 & 21.6 & -- & -- & 18.0 & -- & 1.1 & -- & 46.1 & 5.8 & 41.1 & 17.3 \\
\hline Cyprinidae & 30.2 & -- & 9.1 & 29.3 & 19.9 & 11.3 & 48.1 & -- & 13.9 & 7.0 & 13.4 & 15.4 & 6.2 & 22.2 & 8.5 \\
\hline Decapoda Cambaridae & -- & -- & -- & -- & -- & -- & -- & -- & -- & -- & -- & -- & -- & -- & -- \\
\hline Diptera Tipulidae & -- & -- & -- & -- & -- & -- & -- & -- & -- & -- & -- & -- & -- & -- & -- \\
\hline Ephemeroptera & 7.8 & -- & -- & -- & 3.0 & 57.2 & -- & -- & 7.9 & 45.0 & 45.7 & -- & -- & 3.0 & 33.2 \\
\hline Hymenoptera & -- & -- & -- & -- & -- & -- & 12.2 & -- & -- & 0.5 & -- & 5.1 & -- & -- & 0.3 \\
\hline Ictaluridae & 45.5 & 17.8 & 25.2 & 6.3 & 20.4 & 31.5 & 39.7 & 64.6 & 13.9 & 41.1 & 34.0 & 20.6 & 32.3 & 7.6 & 18.7 \\
\hline Lepidoptera & 6.8 & -- & -- & -- & 2.8 & -- & -- & -- & -- & -- & 1.4 & -- & -- & -- & 0.7 \\
\hline Lepisosteidae & -- & -- & -- & -- & -- & -- & -- & -- & -- & -- & -- & -- & -- & -- & -- \\
\hline Macrobranchium & -- & -- & -- & -- & -- & -- & -- & -- & 26.2 & 2.2 & -- & -- & -- & 4.4 & 0.6 \\
\hline
\end{tabular}


Table 5. Continued

\begin{tabular}{|c|c|c|c|c|c|c|c|c|c|c|c|c|c|c|c|}
\hline & \multicolumn{5}{|c|}{ Dry Year } & \multicolumn{5}{|c|}{ Wet Year } & \multicolumn{5}{|c|}{ TOTAL } \\
\hline & SUM & FAL & WIN & SPR & TOTAL & SUM & FAL & WIN & SPR & TOTAL & SUM & FAL & WIN & SPR & TOTAL \\
\hline Odonata & -- & -- & -- & -- & -- & -- & -- & 17.4 & 9.4 & 1.0 & -- & -- & 5.7 & 3.1 & 0.7 \\
\hline Orthoptera & -- & -- & -- & -- & -- & -- & -- & -- & -- & -- & -- & -- & -- & -- & -- \\
\hline Palaemonidae & 5.4 & -- & -- & 5.2 & 3.1 & -- & -- & -- & 16.1 & 1.2 & 2.1 & -- & -- & 6.7 & 1.3 \\
\hline Percidae & 4.4 & -- & -- & 12.8 & 4.7 & -- & -- & -- & -- & -- & 1.4 & -- & -- & 8.5 & 1.5 \\
\hline Poecilidae & -- & -- & -- & -- & -- & -- & -- & -- & -- & -- & -- & -- & -- & -- & -- \\
\hline Rodentia & -- & -- & -- & -- & -- & -- & -- & -- & 12.7 & 0.9 & -- & -- & -- & 3.4 & 0.4 \\
\hline
\end{tabular}


Table 6. Standardized Electivities $\left(\mathrm{e}_{\mathrm{ij}}\right)$ values as $\% \mathrm{e}_{\mathrm{ij}}$ for prey items consumed by longnose gars in the Brazos River by season, year, and total for both years (TOTAL).

\begin{tabular}{|c|c|c|c|c|c|c|c|c|c|c|c|c|c|c|c|}
\hline & \multicolumn{5}{|c|}{ Dry Year } & \multicolumn{5}{|c|}{ Wet Year } & \multicolumn{5}{|c|}{ TOTAL } \\
\hline & SUM & FAL & WIN & SPR & TOTAL & SUM & FAL & WIN & SPR & TOTAL & SUM & FAL & WIN & SPR & TOTAL \\
\hline Atherinidae & -- & 9.2 & -- & -- & 3.4 & -- & -- & -- & -- & -- & -- & 24.2 & -- & -- & 5.8 \\
\hline Catastomidae & -- & -- & 41.1 & -- & 1.5 & -- & -- & -- & -- & -- & -- & -- & 49.0 & -- & 2.3 \\
\hline Centrarchidae & -- & -- & 45.1 & -- & 13.8 & -- & -- & -- & -- & -- & -- & -- & 23.0 & -- & 9.8 \\
\hline Clupeidae & -- & 51.5 & -- & 73.1 & 47.5 & -- & -- & 2.6 & -- & 0.1 & -- & 62.1 & 0.5 & 64.6 & 9.7 \\
\hline Cyprinidae & 0.0 & -- & 0.0 & 0.0 & 0.0 & 0.0 & 0.1 & -- & 0.0 & 0.0 & 0.0 & 0.0 & 0.0 & 0.0 & 0.0 \\
\hline Ictaluridae & 97.6 & 39.3 & 13.8 & 1.9 & 31.1 & 99.9 & 99.9 & 97.4 & 51.9 & 98.1 & 97.3 & 13.7 & 27.4 & 4.9 & 67.3 \\
\hline Macrobranchium & -- & -- & -- & -- & -- & -- & -- & -- & 47.4 & 1.8 & -- & -- & -- & 8.3 & 1.4 \\
\hline Palaemonidae & -- & -- & -- & 0.0 & 0.6 & -- & -- & -- & 0.7 & 0.1 & 0.9 & -- & -- & 0.1 & 0.2 \\
\hline Percidae & 2.3 & -- & -- & 24.9 & 2.1 & -- & -- & -- & -- & -- & 1.8 & -- & -- & 22.0 & 3.5 \\
\hline Poecilidae & -- & -- & -- & -- & -- & -- & -- & -- & -- & -- & -- & -- & -- & -- & -- \\
\hline Lepisosteidae & -- & -- & -- & -- & -- & -- & -- & -- & -- & -- & -- & -- & -- & -- & -- \\
\hline
\end{tabular}


Table 7. Standardized Electivities $\left(\mathrm{e}_{\mathrm{ij}}\right)$ values as $\% \mathrm{e}_{\mathrm{ij}}$ for prey items consumed by spotted gars in Big Bend oxbow by season, year, and total for both years (TOTAL).

\begin{tabular}{|c|c|c|c|c|c|c|c|c|c|c|c|c|c|c|c|}
\hline & \multicolumn{5}{|c|}{ Dry Year } & \multicolumn{5}{|c|}{ Wet Year } & \multicolumn{5}{|c|}{ TOTAL } \\
\hline & SUM & FAL & WIN & SPR & TOTAL & SUM & FAL & WIN & SPR & TOTAL & SUM & FAL & WIN & SPR & TOTAL \\
\hline Atherinidae & -- & -- & -- & -- & -- & -- & -- & -- & -- & -- & -- & -- & -- & -- & -- \\
\hline Catastomidae & -- & -- & -- & -- & -- & -- & -- & -- & -- & -- & -- & -- & -- & -- & -- \\
\hline Centrarchidae & 4.7 & -- & -- & 11.2 & 7.4 & -- & 0.8 & -- & 100 & 3.5 & 1.5 & 1.4 & -- & 10.9 & 5.7 \\
\hline Clupeidae & 90.3 & -- & -- & -- & 9.5 & 14.9 & 65.4 & 100 & -- & 16.1 & 24.8 & 78.7 & 100 & -- & 15.3 \\
\hline Cyprinidae & 5.0 & -- & -- & -- & 0.2 & -- & -- & -- & -- & -- & 0.7 & -- & -- & -- & 0.1 \\
\hline Ictaluridae & -- & -- & -- & 88.5 & 82.8 & 85.1 & 33.8 & -- & -- & 80.3 & 73.0 & 19.9 & -- & 88.9 & 78.8 \\
\hline Macrobranchium & -- & -- & -- & -- & -- & -- & -- & -- & -- & -- & -- & -- & -- & -- & -- \\
\hline Palaemonidae & 0.1 & -- & -- & -- & 0.0 & -- & -- & -- & -- & -- & 0.0 & -- & -- & -- & 0.0 \\
\hline Percidae & -- & -- & -- & -- & -- & -- & -- & -- & -- & -- & -- & -- & -- & -- & -- \\
\hline Poecilidae & -- & -- & -- & 0.3 & 0.1 & -- & -- & -- & -- & -- & -- & -- & -- & 0.2 & 0.1 \\
\hline Lepisosteidae & -- & -- & -- & -- & -- & -- & -- & -- & -- & -- & -- & -- & -- & -- & -- \\
\hline
\end{tabular}


Table 8. Standardized Electivities $\left(\mathrm{e}_{\mathrm{ij}}\right)$ values as $\% \mathrm{e}_{\mathrm{ij}}$ for prey items consumed by spotted gars in Moehlman's oxbow by season, year, and total for both years (TOTAL).

\begin{tabular}{|c|c|c|c|c|c|c|c|c|c|c|c|c|c|c|c|}
\hline & \multicolumn{5}{|c|}{ Dry Year } & \multicolumn{5}{|c|}{ Wet Year } & \multicolumn{5}{|c|}{ TOTAL } \\
\hline & SUM & FAL & WIN & SPR & TOTAL & SUM & FAL & WIN & SPR & TOTAL & SUM & FAL & WIN & SPR & TOTAL \\
\hline Atherinidae & -- & -- & -- & -- & -- & -- & -- & -- & -- & -- & -- & -- & -- & -- & -- \\
\hline Catastomidae & 15.0 & 80.0 & -- & -- & 32.9 & -- & -- & -- & -- & -- & 1.2 & 76.4 & -- & -- & 2.7 \\
\hline Centrarchidae & 21.0 & 1.5 & -- & -- & 15.5 & 1.8 & 34.2 & -- & 38.7 & 0.9 & 2.8 & 5.4 & -- & 20.1 & 1.9 \\
\hline Clupeidae & 30.3 & 18.6 & 100 & 26.5 & 27.3 & 0.7 & 65.8 & 100 & 60.7 & 1.0 & 2.1 & 18.2 & 100 & 35.1 & 2.4 \\
\hline Cyprinidae & 33.7 & -- & -- & 73.3 & 24.3 & -- & -- & -- & -- & -- & 1.6 & -- & -- & 44.4 & 1.2 \\
\hline Ictaluridae & -- & -- & -- & -- & -- & 97.5 & -- & -- & -- & 98.1 & 92.4 & -- & -- & -- & 91.8 \\
\hline Macrobranchium & -- & -- & -- & -- & -- & -- & -- & -- & -- & -- & -- & -- & -- & -- & -- \\
\hline Palaemonidae & -- & -- & -- & 0.0 & 0.0 & -- & -- & -- & 0.6 & 0.0 & -- & -- & -- & 0.3 & 0.0 \\
\hline Percidae & -- & -- & -- & -- & -- & -- & -- & -- & -- & -- & -- & -- & -- & -- & -- \\
\hline Poecilidae & -- & -- & -- & -- & -- & -- & -- & -- & -- & -- & -- & -- & -- & -- & -- \\
\hline Lepisosteidae & -- & -- & -- & -- & -- & -- & -- & -- & -- & -- & -- & -- & -- & -- & -- \\
\hline
\end{tabular}


Table 9. Standardized Index of Relative Importance (IRI) values as \%IRI for prey items consumed by alligator gars ( $\mathrm{n}=17$ ) in Big Bend and Moehlman's oxbows and total for both oxbows (TOTAL) for fish collected during the wet year.

\begin{tabular}{|c|c|c|c|c|c|c|c|c|c|c|c|}
\hline & \multicolumn{5}{|c|}{ Big Bend } & \multicolumn{5}{|c|}{ Moehlman's } & \multirow{2}{*}{ TOTAL } \\
\hline & SUM & FAL & WIN & SPR & TOTAL & SUM & FAL & WIN & SPR & TOTAL & \\
\hline Amphibia & -- & -- & -- & -- & -- & -- & -- & -- & -- & -- & -- \\
\hline Atherinidae & -- & -- & -- & -- & -- & -- & -- & -- & -- & -- & -- \\
\hline Catastomidae & -- & -- & -- & -- & -- & -- & -- & -- & 100 & 45.3 & 31.7 \\
\hline Centrarchidae & -- & -- & 100 & -- & 18.2 & -- & -- & -- & -- & -- & 69.9 \\
\hline Clupeidae & 35.6 & 100 & -- & 100 & 67.6 & -- & 40.0 & -- & -- & 24.4 & 37.5 \\
\hline Cyprinidae & -- & -- & -- & -- & -- & -- & -- & -- & -- & -- & -- \\
\hline Decapoda Cambaridae & -- & -- & -- & -- & -- & -- & -- & -- & -- & -- & -- \\
\hline Diptera Tipulidae & -- & -- & -- & -- & -- & -- & -- & -- & -- & -- & -- \\
\hline Ephemeroptera & -- & -- & -- & -- & -- & -- & -- & -- & -- & -- & -- \\
\hline Hymenoptera & -- & -- & -- & -- & -- & -- & -- & -- & -- & -- & -- \\
\hline Ictaluridae & 64.4 & -- & -- & -- & 14.2 & 64.4 & -- & -- & -- & 14.2 & 14.3 \\
\hline Lepidoptera & -- & -- & -- & -- & -- & -- & -- & -- & -- & -- & -- \\
\hline Lepisosteidae & -- & -- & -- & -- & -- & -- & 32.8 & -- & -- & 16.0 & 9.5 \\
\hline Macrobranchium & -- & -- & -- & -- & -- & -- & -- & -- & -- & -- & -- \\
\hline
\end{tabular}


Table 9. Continued

\begin{tabular}{|c|c|c|c|c|c|c|c|c|c|c|c|}
\hline & \multicolumn{5}{|c|}{ Big Bend } & \multicolumn{5}{|c|}{ Moehlman's } & \multirow{2}{*}{ TOTAL } \\
\hline & SUM & FAL & WIN & SPR & TOTAL & SUM & FAL & WIN & SPR & TOTAL & \\
\hline Odonata & -- & -- & -- & -- & -- & -- & -- & -- & -- & -- & -- \\
\hline Orthoptera & -- & -- & -- & -- & -- & -- & -- & -- & -- & -- & -- \\
\hline Palaemonidae & -- & -- & -- & -- & -- & -- & -- & -- & -- & -- & -- \\
\hline Percidae & -- & -- & -- & -- & -- & -- & -- & -- & -- & -- & -- \\
\hline Poecilidae & -- & -- & -- & -- & -- & -- & -- & -- & -- & -- & -- \\
\hline Rodentia & -- & -- & -- & -- & -- & -- & -- & -- & -- & -- & -- \\
\hline
\end{tabular}


Table 10. Standardized Electivities $\left(\mathrm{e}_{\mathrm{ij}}\right)$ values as \% $\mathrm{e}_{\mathrm{ij}}$ for prey items consumed by alligator gars $(\mathrm{n}=17)$ at Big Bend and Moehlman's oxbow by season during the wet year, and total for both sites (TOTAL).

\begin{tabular}{|c|c|c|c|c|c|c|c|c|c|c|c|c|c|c|c|}
\hline & \multicolumn{5}{|c|}{ Big Bend } & \multicolumn{5}{|c|}{ Moehlman's } & \multicolumn{5}{|c|}{ TOTAL } \\
\hline & SUM & FAL & WIN & SPR & TOTAL & SUM & FAL & WIN & SPR & TOTAL & SUM & FAL & WIN & SPR & TOTAL \\
\hline Atherinidae & -- & -- & -- & -- & -- & -- & -- & -- & -- & -- & -- & -- & -- & -- & -- \\
\hline Catastomidae & -- & -- & -- & -- & -- & -- & -- & -- & 100 & 84.1 & -- & -- & -- & 99.9 & 55.9 \\
\hline Centrarchidae & -- & -- & 100 & -- & 4.5 & -- & -- & -- & -- & -- & -- & -- & 100 & -- & 0.1 \\
\hline Clupeidae & 5.2 & 100 & -- & 100 & 29.0 & -- & 0.1 & -- & -- & 0.0 & 1.2 & 0.2 & -- & 0.0 & 0.4 \\
\hline Cyprinidae & -- & -- & -- & -- & -- & -- & -- & -- & -- & -- & -- & -- & -- & -- & -- \\
\hline Ictaluridae & 94.8 & -- & -- & -- & 66.5 & -- & 41.7 & -- & -- & 5.2 & 98.8 & 6.2 & -- & -- & 7.2 \\
\hline Macrobranchium & -- & -- & -- & -- & -- & -- & -- & -- & -- & -- & -- & -- & -- & -- & -- \\
\hline Palaemonidae & -- & -- & -- & -- & -- & -- & -- & -- & -- & -- & -- & -- & -- & -- & -- \\
\hline Percidae & -- & -- & -- & -- & -- & -- & -- & -- & -- & -- & -- & -- & -- & -- & -- \\
\hline Poecilidae & -- & -- & -- & -- & -- & -- & -- & -- & -- & -- & -- & -- & -- & -- & -- \\
\hline Lepisosteidae & -- & -- & -- & -- & -- & -- & 58.2 & -- & -- & 10.7 & -- & 93.6 & -- & -- & 36.4 \\
\hline
\end{tabular}


For the statistical analysis of the diet composition data, the first two axes of PCA combined to explain $65.3 \%$ of the variation in diet (Table 11). Axis 1 loadings from low to high include: crayfish (0.108), minnows (0.159), catfish (0.406), and shad (3.651). Axis 2 loadings from low to high include: shad (-0.439), crayfish (0.250), sunfish (0.641), and catfish (2.713). In Big Bend oxbow, crayfish were important in the diet of spotted gars during the dry year when fish prey items were declining in abundance (Total prey fish CPUE: summer - 62.1, fall - 19.7, winter - 5.8, spring - 19.8) (Figure 4). After the river connected with the oxbow during the summer of the dry year and spring of the wet year, there were shifts toward greater shad consumption. Similarly, catfish were the most important prey item for longnose gars in the Brazos River, and after the river connected with the oxbow during the fall and spring floods of the dry year, shad became the most important prey item (Figure 5). Shad abundance was low in the river prior to oxbow connection events (Figure 6). Moehlman's oxbow had low frequencies of hydrological connections, and spotted gars in this oxbow had a relatively stable diet dominated by shad (Figure 7). Following flood connections during the spring of the dry year and summer of the wet year in Moehlman's oxbow, spotted gar diets included more catfish, but later switched back to shad.

Dietary Overlap

Dietary overlap between the two most common gar species, longnose and spotted combined across all habitats between years was high: $72.7 \%$ during the dry year and 
90.1\% during the wet year (Table 12). Dietary overlap between longnose and alligator gars was $41 \%$, and between spotted and alligator gars was $43 \%$ during the wet year (alligator gar diet data were only analyzed for the wet year). Dietary overlap between longnose and spotted gars varied seasonally. During the dry year, dietary overlap was highest in fall, which coincided with a hydrological connection with Big Bend oxbow (Figure 2). During the wet year, summer and winter had higher dietary overlaps, which coincided with hydrologic connections between the river and both oxbows.

Predator-Prey Size Relationships

Predator-prey size relationships (Figure 8) were examined based on 311 measurable prey items for spotted gars, and 123 measurable prey items for longnose gars. Most of the prey consumed by longnose and spotted gars were 30 to $80 \mathrm{~mm}$. The average size of prey consumed by spotted and longnose gars was 55 and $65.7 \mathrm{~mm}$, respectively. Based on linear regression, prey size significantly increased as predator weight increased for both longnose and spotted gars (Longnose gar: $\mathrm{SL}_{\text {prey }}=0.47\left[\mathrm{~W}_{\mathrm{gar}}\right]+$ $0.27, \mathrm{R}^{2}=0.21, \mathrm{~F}_{1,310}=45.3, \mathrm{P}<0.001 ;$ Spotted gar: $\mathrm{SL}_{\text {prey }}=0.17\left[\mathrm{~W}_{\text {gar }}\right]+1.24, \mathrm{R}^{2}=$ $\left.0.13, \mathrm{~F}_{1,122}=32.19, \mathrm{P}<0.001\right)$. Interspecific difference in the slope of the predator-prey relationship could not be determined due to a significant interaction between gar species and weight (ANCOVA: $\left.\mathrm{F}_{2,434}=35.7, \mathrm{P}<0.001\right)$. 
Table 11. PCA axis loadings and eigenvalues (each with $\mathrm{p}<0.05$ ) based on volumetric proportions of prey items according to gar species, sample site, and season.

\begin{tabular}{|c|c|c|}
\hline & Axis 1 & Axis 2 \\
\hline Eigenvalue & 0.4849 & 0.1684 \\
\hline Amphibia & 0.0096 & 0.0001 \\
\hline Atherinidae & 0.0073 & 0.0001 \\
\hline Catastomidae & 0.0382 & 0.0911 \\
\hline Centrarchidae & 0.6243 & 0.6414 \\
\hline Clupeidae & 0.1591 & 0.3709 \\
\hline Cyprinidae & 0.108 & 0.2495 \\
\hline Decapoda Cambaridae & 0.0005 & 0.0001 \\
\hline Diptera Tipulidae & 3.6508 & -0.4391 \\
\hline Ephemeroptera & 0.0067 & 0.1179 \\
\hline Hymenoptera & 0.002 & 0.0321 \\
\hline Ictaluridae & 0.0031 & 0.0504 \\
\hline Lepidoptera & 0.0011 & 0.0168 \\
\hline Lepisosteidae & 0.0001 & 0.0006 \\
\hline Macrobranchium & 0.0149 & 0.053 \\
\hline Odonata & 0.0541 & 0.09 \\
\hline Orthoptera & 0.4064 & 2.7131 \\
\hline Palaemonidae & 0.0006 & 0.0098 \\
\hline Percidae & 0.0167 & 0.012 \\
\hline Poecilidae & 0.001 & 0.0166 \\
\hline Rodentia & 0.0477 & 0.078 \\
\hline
\end{tabular}



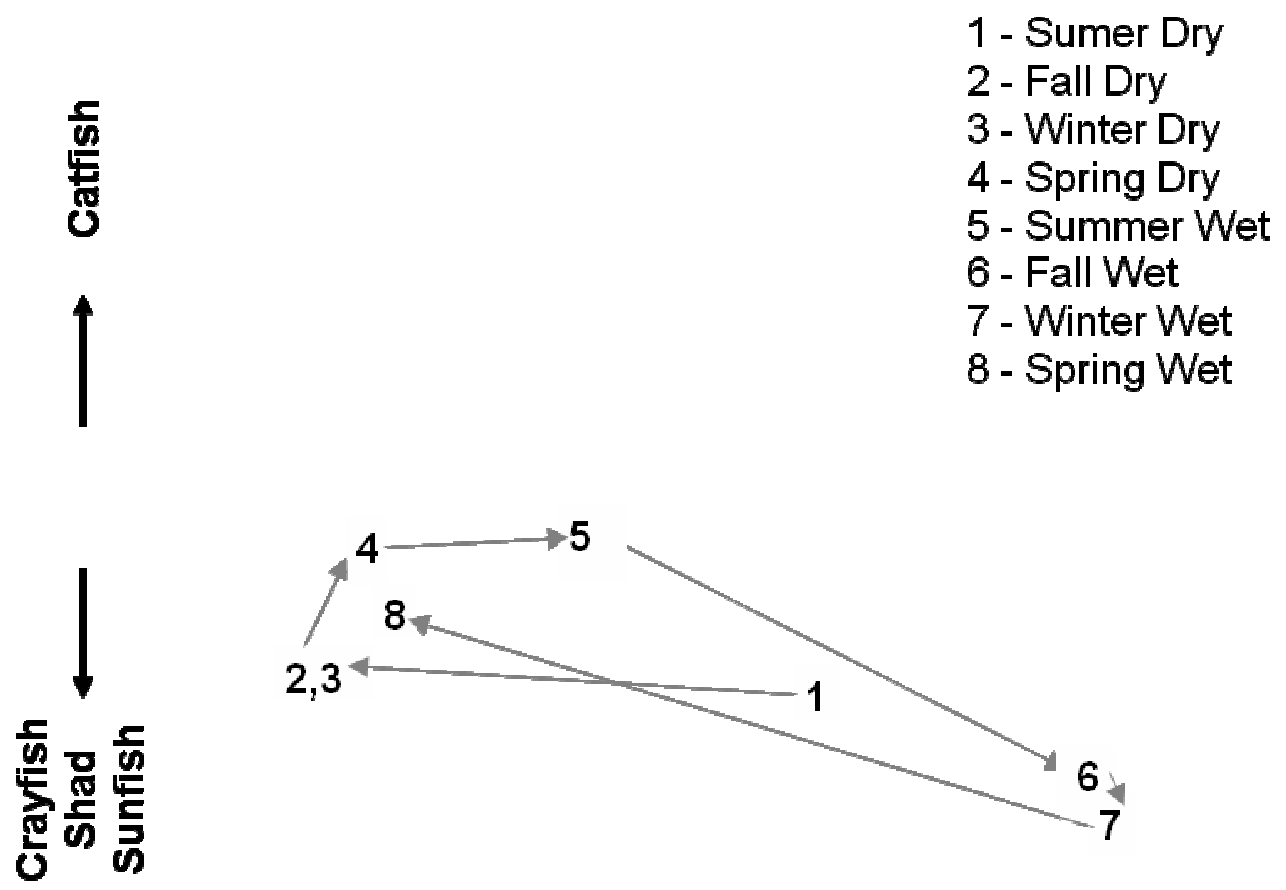

\section{Catfish \\ Crayfish} Minnows

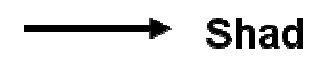

Figure 4. PCA ordination plot based on seasonal volumetric proportions of diet items for spotted gars in Big Bend oxbow. 


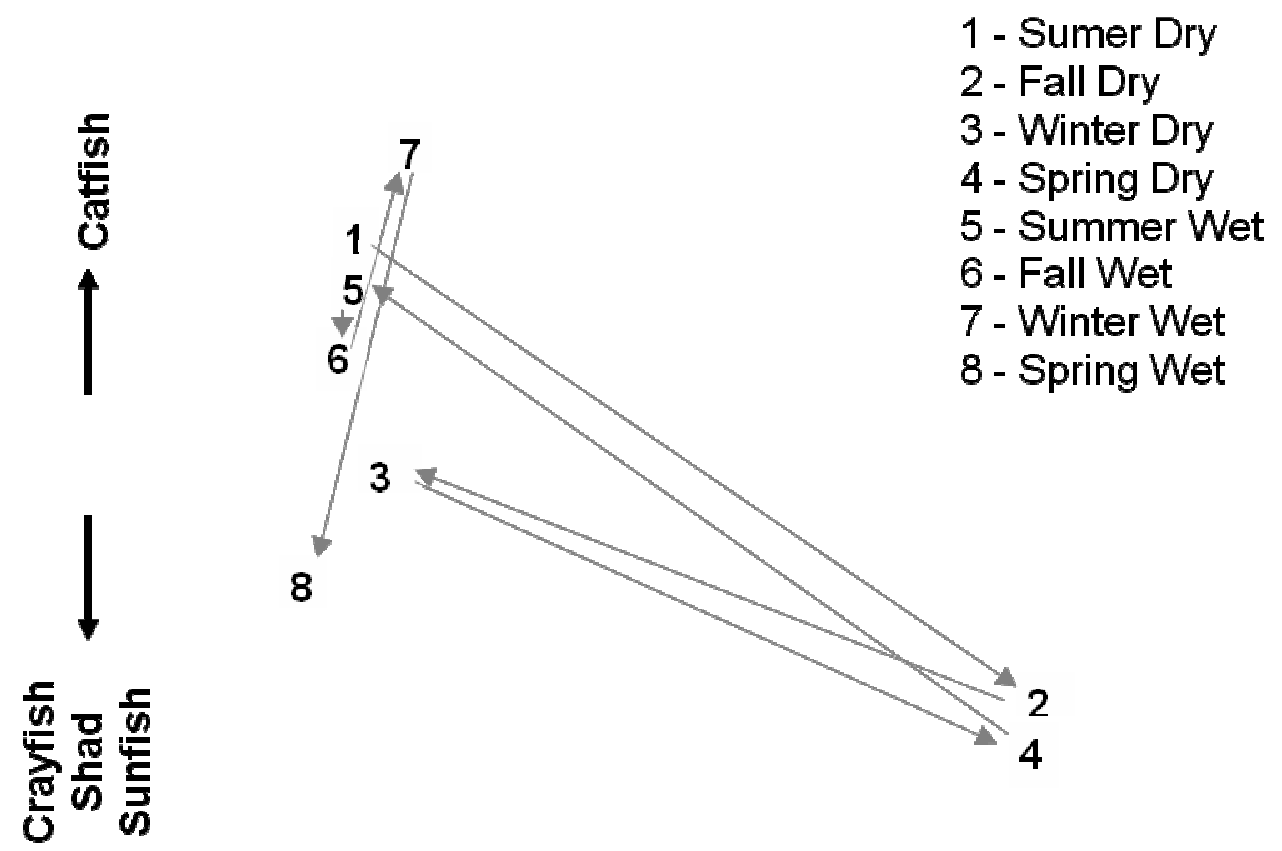

Catfish

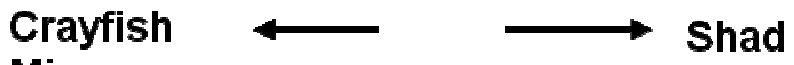

Figure 5. PCA ordination plot based on seasonal volumetric proportions of diet items for longnose gars in the Brazos River. 

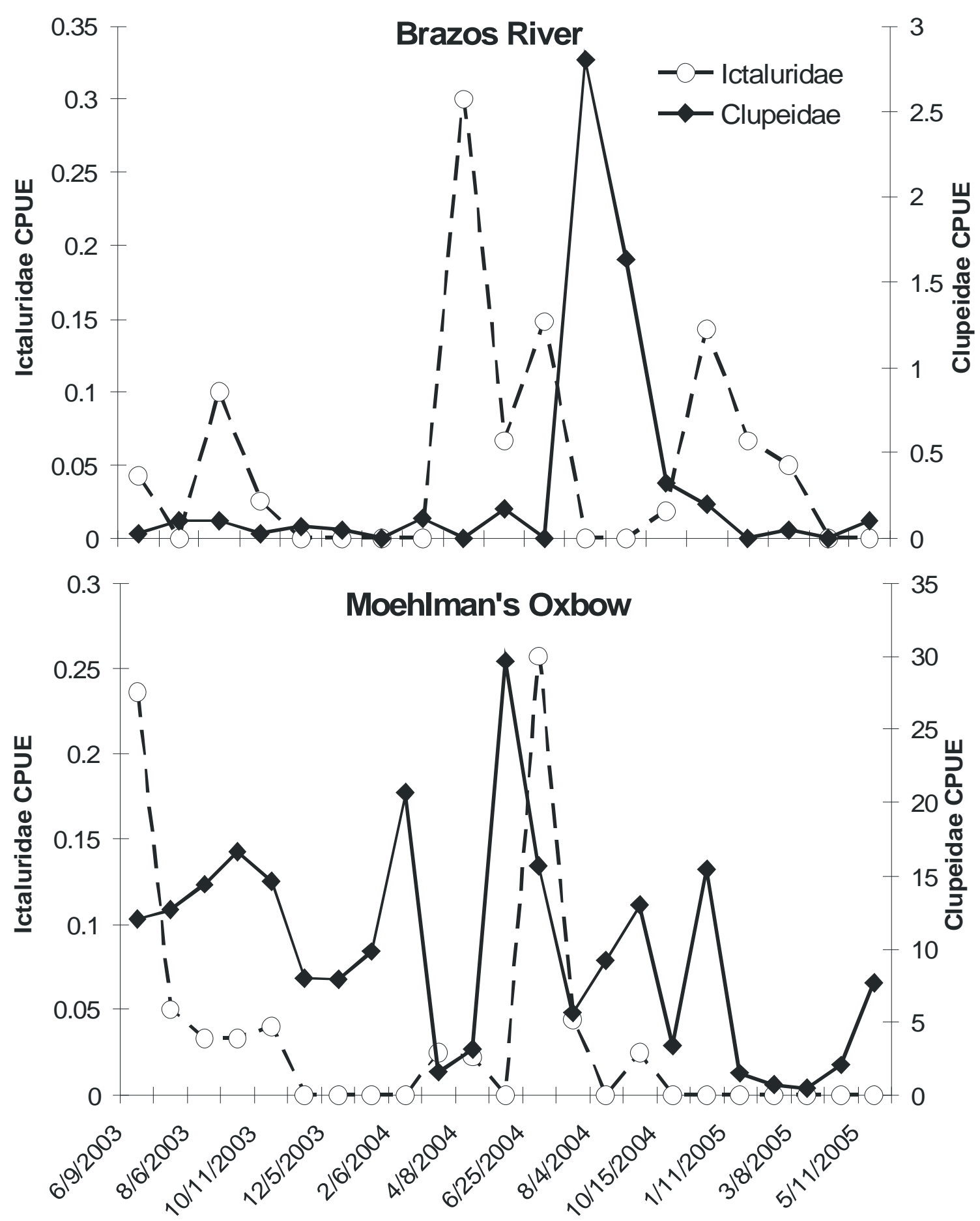

Figure 6. Changes in abundance of shad (Clupeidae) and catfish (Ictaluridae) during the two year sampling period in the Brazos River and Moehlman's oxbow. CPUE for shad and catfish are at different scales on the Y-axis. 


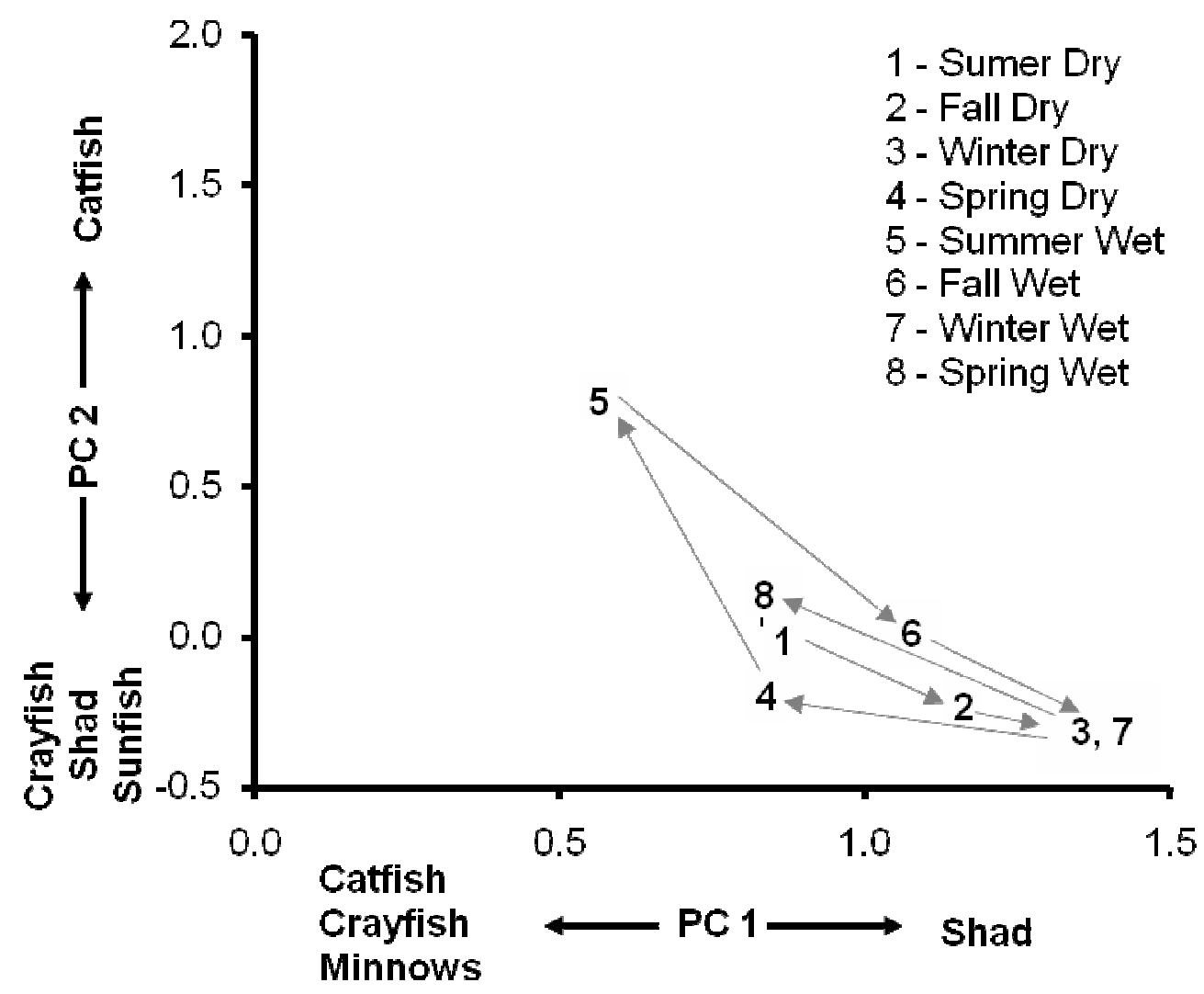

Figure 7. PCA ordination plot based on seasonal volumetric proportions of diet items for spotted gars in Moehlman's oxbow. 
Table 12. Standardized seasonal niche overlap values between species pairs for both dry and wet years.

\begin{tabular}{|c|c|c|c|}
\hline & & Dry Year & Wet Year \\
\hline & SUM & 0.3670 & 0.7196 \\
\hline Spotted Gar & FAL & 0.9709 & 0.7011 \\
\hline$X$ & WIN & 0.6497 & 0.9919 \\
\hline \multirow[t]{3}{*}{ Longnose Gar } & SPR & 0.1462 & 0.1734 \\
\hline & TOTAL & 0.7272 & 0.9006 \\
\hline & SUM & -- & 0.7108 \\
\hline Spotted Gar & FAL & -- & 0.7829 \\
\hline$X$ & WIN & -- & 0.0000 \\
\hline \multirow[t]{3}{*}{ Alligator Gar } & SPR & -- & 0.0289 \\
\hline & TOTAL & -- & 0.4109 \\
\hline & SUM & -- & 0.4549 \\
\hline Longnose Gar & FAL & -- & 0.7509 \\
\hline $\mathrm{X}$ & WIN & -- & 0.0784 \\
\hline \multirow[t]{2}{*}{ Alligator Gar } & SPR & -- & 0.1660 \\
\hline & TOTAL & -- & 0.4311 \\
\hline
\end{tabular}




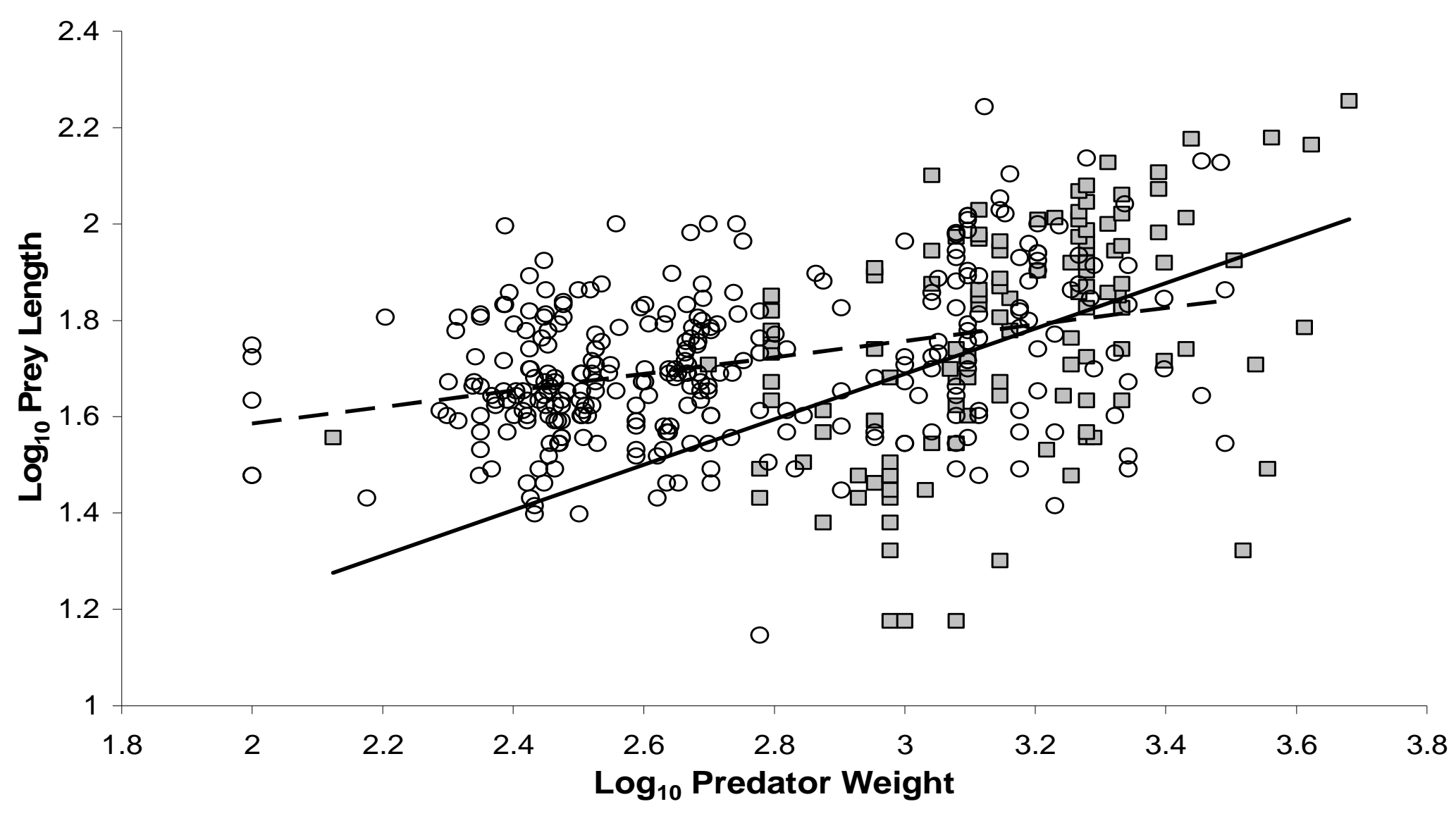

Figure 8. Relationship between log transformed prey standard length and log transformed gar weight.

$(\bigcirc=$ L. oculatus, $\square=$ L. osseus $)$ 


\section{DISCUSSION}

\section{Habitat Partitioning}

As I hypothesized, gar would either partition diet or habitat and CPUE values suggest strong habitat partitioning between spotted and longnose gars in the Brazos River, with spotted gars most abundant in oxbows and longnose gars most abundant in the river channel. Similar habitat preferences in gars have been reported from other systems (Holloway 1954, Goodyear 1967, Snedden et al. 1999). Even during the wet

year, with frequent lateral connections that provided corridors for gars to move between habitats, spotted gars remained within oxbow habitats (spotted gar CPUE did significantly decreased between years, but this likely was due to a doubling of water volume in oxbow habitats during the wet year) indicated by few spotted gar being captured in the river channel during periods of connection, unlike my hypothesis. Longnose gars, however, significantly increased in abundance in oxbow habitats during the wet year, indicative of longnose gars from the river moving into oxbow habitats during connection events as I hypothesized.

Movement of riverine species into floodplain habitats during lateral connections has been well documented (Ross and Baker 1983, Kwak 1988, Miranda and Lucas 2004, Miranda 2005, Zeug et al. 2005). Many channel-dwelling fishes move onto floodplain habitats to spawn (Hohausová et al. 2003, Penczak et al. 2003) or to exploit the abundant food resources associated with off-channel habitats (Winemiller and Kelso- 
Winemiller 1994, O’Connell 2003). Longnose gars apparently enter oxbows to forage opportunistically on abundant prey rather than for spawning, since longnose gar seem to be stream spawners that require flow (Netsch and Witt 1962, Johnson and Noltie 1996). Conversly, spotted gars seem to prefer backwaters or areas with little or no flow for spawning (Echelle and Riggs 1972, Love 2004).

Alligator gars appeared to move into oxbow habitats during flood connections. Although based on a limited sample $(\mathrm{n}=19)$, alligator gar abundance significantly increased in oxbow habitats during the wet year, and all were juveniles. The alligator gar size distribution probably was skewed due to gear sampling bias. Throughout the study, there was evidence of large fish escaping capture (large holes in the multifilament gillnet), and a large alligator gar was observed in Big Bend oxbow during a flood connection. Adult alligator gars may move into oxbow habitats during floods to exploit abundant prey, and subsequently return to the river channel. In contrast, juvenile alligator gars appear to remain in oxbows for extended periods. There was no evidence that juvenile longnose gar moved into, or remained within oxbow habitats, based on average SL of longnose gars in the two habitats (river $=727 \mathrm{~mm}$, oxbow $=700 \mathrm{~mm}, \chi^{2}$ $=0.511, \mathrm{df}=1, \mathrm{p}=0.48)$. A potential advantage of juveniles remaining in oxbow habitats is enhanced foraging, growth and survival, which have been shown in other species (Sommer et al. 2001). 


\section{Diet Partitioning}

Due to the high degree of habitat partitioning and based on high diet overlap, spotted and longnose gars do not seem to partition food resources as I hypothesized. Other studies of piscivorous fishes in rivers have shown that diets often are similar for species that partition habitats (Jepsen and Winemiller 1997, Sala and Ballesteros 1997, Wheeler and Allen 2003). Diet partitioning may be more prevalent among species that co-occur in the same habitat (Winemiller 1989, Bacheler et al. 2004, Pelicice and Agostinho 2006). Fishes comprised a major portion of the diet of both spotted and longnose gars, but they were not strict piscivores (Appendix I). The two species consumed both aquatic and terrestrial invertebrates, and longnose gars consumed terrestrial vertebrates as well.

As I hypothesized, river-floodplain connections played an important role in structuring the diet of gars in both river and oxbow habitats. For spotted gar in oxbow habitats, the physical and environmental characteristics of oxbows determine fish assemblage structure, and fish assemblages in Big Bend and Moehlman's oxbow differ, especially during periods of isolation (Winemiller et al. 2000, Zeug et al. 2005). These differences in fish assemblage structure were reflected in the diets of spotted gars in the two habitats, were gars tend to consume prey in proportion to their availability (Holloway 1954, Goodyear 1967, Dugas et al. 1976, Seidensticker 1987, Snedden et al. 1999). In Big Bend, sunfish were the most abundant fish (46.1\% of total prey fish CPUE) and also were the most important fish in the diets of spotted gars. Crayfish, 
however, were the most important food item overall for spotted gars in Big Bend oxbow. Crayfish were abundant (C.R.R. and S.C.Z. personal observation) during the fall and winter of the dry year when Big Bend oxbow was desiccating and fish abundances decreased. For a 6-month period (fall and winter of the dry year), spotted gars in Big Bend consumed only crayfish until a flood connection in the spring refilled the oxbow. In Moehlman's oxbow, shad were the most abundant fish (38\% of total prey fish CPUE), and also were the most important prey in spotted gar diets.

Longnose gars in the Brazos River did not seem to follow this trend of consuming the most abundant food resource in their habitat. In the Brazos River, minnows were the most abundant fish, but comprised only a small portion (8.5\%) of longnose gar diets. Based on electivities, longnose gars were strongly selecting against minnows. Similarly, spotted gars selected against the second most abundant fish in both oxbows, mosquitofish (Poeciliidae), with only one individual consumed during the entire 2-yr study. Gars probably select against minnows and mosquitofish because of their small size. Minnows and mosquitofish are among the smallest fishes in the system and are probably not easily detected or captured by gars (Lundvall et al. 1999, Dörner and Wagner 2003).

In tropical floodplain systems, fishes have been shown to increase their diet breadth during flood periods (Winemiller and Kelso-Winemiller 1994, Balcombe et al. 2005). Spotted gars in both Big Bend and Moehlman's oxbows (Figure 2) followed this pattern, with greater diet breadth during the wet year. Moreover, seasonal increases in 
diet breadth within years coincided with connections with the river channel. However the opposite was observed for the longnose gar. Instead Longnose gars appear to take advantage of abundant prey associated with oxbow habitats, such as shad, as indicated by a decrease in diet breadth during the wet year, and seasonally within years, coinciding with river channel connections as I predicted. Longnose gars seem to forage opportunistically on pulses of abundant prey according to flood dynamics. During flood connections (Figure 2), shad were an important component in diets of longnose gars in the river channel. Shad abundances are typically low in the river channel, and high in oxbows and floodplain lakes (Winemiller et al. 2000, Miranda 2005, Barko et al. 2006, Pegg et al. 2006). Shad abundance increased in the Brazos River channel following flood connections (Figure 6). This difference in prey spatial distributions creates a pulsed food subsidy (Winemiller and Jepsen 2004, Hoeinghaus et al. 2006) for longnose gars in the river channel. Based on electivity values, longnose gars selected shad when their abundance in the river channel was high following river-oxbow connections (Dry year: fall $-51.5 \%$, spring $-73.1 \%$; Wet year: summer $-95.9 \%$, winter $-99.5 \%)$. The relative size (Lundvall et al. 1999, Dörner and Wagner 2003, Gill 2003) and mobility (Savino and Stein 1989, Ostrand et al. 2004) of shad probably make them vulnerable to large sit-and-wait predators such as gars.

Similarly, spotted gars in Brazos River oxbow habitats benefited from pulsed subsidies that moved from the river channel into oxbow habitats. In both oxbows, floods were followed by increased abundance of juvenile catfish, more than likely originating from the river channel. As a result, catfish were the most selected prey for spotted gars 
in oxbows, as well as longnose gars in the river channel. Allochthonous food resources also were found in the diets of spotted gars. Grasshoppers were the most important diet item for spotted gars in Big Bend during the summer flood of the wet year when numerous grasshoppers were observed on the water surface of an inundated pasture.

The physical characteristics of oxbows (connection frequency) influence gar diets as well. Among the three habitats sampled, the river channel is the most dynamic habitat, followed by Big Bend oxbow which connects frequently with the river channel. Moehlman's oxbow requires higher flow rates for lateral connections with the river channel and therefore is a relatively stable environment. This pattern was strongly reflected in the diet ordinations. In Big Bend oxbow, diets shifted from crayfish during 6 months when the oxbow was desiccating, to a diet dominated by fishes brought into the oxbow during a flood. In the Brazos River, catfish were the most important prey of longnose gars, but the diet shifted toward greater shad consumption following floods. Spotted gars in Moehlman's oxbow had a relatively stable diet comprised mostly of shad and sunfish, but they consumed more catfish after floods. Thus, relatively unpredictable flood pulses seem to be an important factor controlling upper food web dynamics in this temperate lowland river. 


\section{CONCLUSIONS}

It is apparent from this research that river-floodplain connectivity plays a vital role in the ecology of gars in the middle Brazos River. Not only do floods structure the diet of these fishes by facilitating pulses of food subsidies, but more importantly, floods are essential for maintaining the populations of spotted gar and alligator gar in the river. Floods provide habitats for spotted gar (by keeping oxbow from desiccating and providing access to these essential habitats) and essential nursery habitat for juvenile alligator gar which access oxbow habitats during connection events. For longnose gar, floods provide important prey resources through pulses of shad from oxbows during connections, or by allowing them access to highly productive oxbow habitats to forage. Any anthropogenic alterations to the hydrology of the middle Brazos River, especially any that would limit or reduce floodplain connectivity would certainly be a disaster for the ecology of this relatively unaltered river-floodplain system, but would more than likely reduce the spotted and alligator gar populations in the river. Any alteration of the population structure of an apex predator is highly undesirable. Because of their status as an apex predator and high abundance, increased knowledge of the ecology of these species would be appear to be very important.

Understanding the habitat and diet preferences of gars is an important first step in gaining knowledge of the ecology of these species, but more research and information is essential. Such future research should include age and growth data of gars in the Brazos 
River, which is essential information for the proper management of a species, but is lacking for these species. Relating growth to hydrology would also be important to further understand the role of river-floodplain connections in the ecology of gars. Understanding gar movements between habitats and seasonally during flood events would also be important ecological information that is lacking for the ecology of these species. This information is essential for the management of these species, especially in the event of anthropogenic alterations to the middle Brazos River. It is time for natural resource managers across the country discontinue viewing gars as a 'trash' or 'rough' fish, and to appreciate them as important, native apex predators with unique evolutionary histories and essential roles in freshwater ecosystems. 


\section{REFERENCES}

Arthington, A.H., Bunn, S.E., Poff, N.L., \& Naiman, R.J. 2006. The challenge of providing environmental flow rules to sustain river ecosystems. Ecological Applications 16(4): 1311-1318.

Bacheler, N.M., Neal, J.W., \& Noble, R.L. 2004. Diet overlap between native bigmouth sleepers (Gobiomorus dormitor) and introduced predatory fishes in a Puerto Rico reservoir. Ecology of Freshwater Fish 13: 111-118.

Balcombe, S.R., Bunn, S.E., McKenzie-Smith, F.J., \& Davies, P.M. 2005. Variability of fish diets between dry and flood periods in an arid floodplain river. Journal of Fish Biology 67: 1552-1567.

Barko, V.A., Herzog, D.P., \& O’Connell, M.T. 2006. Response of fishes to floodplain connectivity during and following a 500-year flood event in the unimpounded Upper Mississippi River. Wetlands 26 (1): 244-257.

Bayley, P.B. 1991. The flood pulse advantage and the restoration of river-floodplain systems. Regulated Rivers: Research \& Management 6: 75-86.

Bayley, P.B. 1995. Understanding large river-floodplain ecosystems. BioScience 45(3): 153-158.

Bonham, K. 1941. Food of gars in Texas. Transactions of the American Fisheries Society 70: 356-362. 
Buijse, A.D., Coops, H., Staras, M., Jans, L.H., Van Geest, G.J., Grifts, R.E., Ibelngs, B.W., Oosterberg, W., \& Roozen, F.C.J.M. 2002. Restoration strategies for river floodplains along large lowland rivers in Europe. Freshwater Biology 47: 889907.

Crumpton, J. 1971. Food habits of longnose gar (Lepisosteus osseus) and Florida gar (Lepisosteus platyrhincus) collected from five Central Florida lakes. Proceedings of the Annual Conference of the Southeastern Association of Game and Fish Commissioners 24(1970): 419-424.

Dörner, H. \& Wagner, A. 2003. Size-dependent predator-prey relationships between perch and their fish prey. Journal of Fish Biology 62: 1021-1032.

Dugas, C.N., Konikoff, M., \& Trahan, M.F. 1976. Stomach contents of bowfin (Amia clava) and spotted gar (Lepisosteus oculatus) taken in Henderson Lake, Louisiana. Proc. LA Acad. Sci. 39: 28-34.

Dynesius, M. \& Nilsson, C. 1994. Fragmentation and flow regulation of river systems in the northern third of the world. Science 266: 753-762.

Echelle, A.A. \& Riggs, C.D. 1972. Aspects of the early life history of gars (Lepisosteus) in Lake Texoma. Transactions of the American Fisheries Society 101 (1): 103112. 
Galat, D.L., Fredrickson, L.H., Humburg, D.D., Bataille, K.J., Bodie, J.R., Dohrenwend, J., Gelwicks, G.T., Havel, J.E., Helmers, D.L., Hooker, J.B., Jones, J.R., Knowlton, M.F., Kubisiak, J., Mazourek, J., McColpin, A.C., Renken, R.B., \& Semlitsch, R.D. 1998. Flooding to restore connectivity of regulated, large-river wetlands. BioScience 48(9): 721-733.

Gill, A.B. 2003. The dynamics of prey choice in fish: the importance of prey size and satiation. Journal of Fish Biology 63: 105-116.

Goodyear, C.P. 1967. Feeding habits of three species of gars, Lepisosteus, along the Mississippi Gulf Coast. Transactions of the American Fisheries Society 96 (3): 297-300.

Helfman, G.S., Collette, B.B., \& Facey, D.E. 1999. The diversity of fishes. Malden, Massachusetts, Blackwell Science.

Hoeinghaus, D.J., Winemiller, K.O., Layman, C.A., Arrington, D.A., \& Jepsen, D.B. 2006. Effects of seasonality and migratory prey on body condition of Cichla species in a tropical floodplain river. Ecology of Freshwater Fish 15: 398-407.

Hohausová, E. 2000. Exchange rate and small-scale movements of fish between a river and its backwater. Archiv für Hydrobiologie 147(4): 485-504.

Hohausová, E., Copp, G.H., \& Jankovský, P. 2003. Movement of fish between a river and its backwater: diel activity and relation to environmental gradients. Ecology of Freshwater Fish 12: 107-117. 
Holloway, A.D. 1954. Notes on the life history and management of the shortnose and longnose gars in Florida waters. Journal of Wildlife Management 18 (4): 438449.

Jepsen, D.B., Winemiller, K.O., \& Taphorn, D.C. 1997. Temporal patterns of resource partitioning among Cichla species in a Venezuelan blackwater river. Journal of Fish Biology 51: 1085-1108.

Johnson, B.L. \& Noltie, D.B. 1996. Migratory dynamics of stream-spawning longnose gar (Lepisosteus osseus). Ecology of Freshwater Fish 5: 97-107.

Junk, W.J., Bayley, P.B., \& Sparks, R.E. 1989. The flood pulse concept in riverfloodplain systems. Canadian Special Publication of Fisheries and Aquatic Sciences 106: 110-127.

Junk, W.J. 1999. The flood pulse concept of large rivers: learning from the tropics. Archiv für Hydrobiologie Supplement 115(3): 261-280.

Kwak, T.J. 1988. Lateral movement and use of floodplain habitat by fishes of the Kankakee River, Illinois. The American Midland Naturalist 120 (2): 241-249.

Lagler, K.F. \& Hubbs, F.V. 1940. Food of long-nosed gar (Lepisosteus osseus oxyurus) and bowfin (Amia calva) in Southern Michigan. Copeia 1940 (4): 239-241.

Lagler, K.F., Obrecht, C.B., \& Harry, G.V. 1942. The food habits of gars (Lepisosteus spp.) considered in relation to fish management. Investigations of Indiana Lakes and Streams 2: 117-135. 
Love, J.W. 2004. Age, growth, and reproduction of spotted gar, Lepisosteus oculatus (Lepisosteidae), from the Lake Pontchartrain Estuary, Louisiana. The Southwestern Naturalist 49 (1): 10-23.

Lundvall, D., Svanbäck, R., Persson, L., \& Byström, P. 1999. Size-dependent predation in piscivores: interactions between predator foraging and prey avoidance abilities. Canadian Journal of Fisheries and Aquatic Sciences 56: 1285-1292.

Miranda, L.E. \& Lucas, G.M. 2004. Determinism in fish assemblages of floodplain lakes of the vastly disturbed Mississippi Alluvial Valley. Transactions of the American Fisheries Society 133: 358-370.

Miranda, L.E. 2005. Fish assemblages in oxbow lakes relative to connectivity with the Mississippi River. Transactions of the American Fisheries Society 134: 14801489.

Netsch, N.F. \& Witt, A., Jr. 1962. Contributions to the life history of the longnose gar, (Lepisosteus osseus) in Missouri. Transactions of the American Fisheries Society 91: 251-262.

Nilsson, C., Reidy, C.A., Dynesius, M., \& Revenga, C. 2005. Fragmentation and flow regulation of the world's large river systems. Science 308: 405-408.

O'Connell, M.T. 2003. Direct exploitation of prey on an inundated floodplain by cherryfin shiners (Lythrurus roseipinnis) in a low order, blackwater stream. Copeia 3: 635-645. 
Ostrand, K.G., Braeutigam, B.J., \& Wahl, D.H. 2004. Consequence of vegetation density and prey species on spotted gar foraging. Transactions of the American Fisheries Society 133: 794-800.

Pegg, M.A., Irons, K.S., O’Hara, T.M., \& McClelland M.A. 2006. Initial response of a floodplain lake fish community to water-level stabilisation. Ecology of Freshwater Fish 15: 40-47.

Pelicice, F.M. \& Agostinho, A.A. 2006. Feeding ecology of fishes associated with Egeria spp. patches in a tropical reservoir, Brazil. Ecology of Freshwater Fish 15: $10-19$.

Penczak, T., Zięba, G., Koszaliński, H., \& Kruk, A. 2003. The importance of oxbow lakes for fish recruitment in a river system. Arch. Hydrobiol. 158 (2): 267-281.

Pianka, E.R. 1974. Niche overlap and diffuse competition. Proceedings of the National Academy of Sciences USA 71 (5): 2141-2145.

Pinkas, L., Oliphant, M.S., \& Iverson, I.L.K. 1971. Food habits of albacore, bluefin tuna and bonito in Californian waters. California Fish and Game 152: 1-105.

Poff, N.L., Allan, D., Bain, M.B., Karr, J.R., Prestegaard, K.L., Richter, B.D., Sparks, R.E., \& Stromberg, J.C. 1997. The natural flow regime. BioScience 47(11): 769784. 
Pringle, C.M., Freeman, M.C., \& Freeman, B.J. 2000. Regional effects of hydrologic alterations on riverine macrobiota in the new world: tropical-temperate comparisons. BioScience 50(9): 807-823.

Rosenberg, D.M., McCully, P., \& Pringle, C.M. 2000. Global-scale environmental effects of hydrological alterations: Introduction. BioScience 50(9): 746-751.

Ross, S.T. \& Baker, J.A. 1983. The response of fishes to periodic spring floods in a southeastern stream. The American Midland Naturalist 109 (1): 1-14.

Sala, E. \& Ballesteros, E. 1997. Partitioning of space and food resources by three fish of the genus Diplodus (Sparidae) in a Mediterranean rocky infralittoral ecosystem. Marine Ecology Progress Series 152: 273-283.

Savino, J.F. \& Stein, R.A. 1989. Behavior of fish predators and their prey: habitat choice between open water and dense vegetation. Environmental Biology of Fishes 24 (4): 287-293.

Seidensticker, E.P. 1987. Food selection of alligator gar and longnose gar in a Texas reservoir. Proceedings of the Annual Conference Southeastern Association of Fish and Wildlife Agencies 41 (1987): 100-104.

Snedden, G.A., Kelso, W.E., \& Rutherford, D.A. 1999. Diel and seasonal patterns of spotted gar movement and habitat use in the Lower Atchafalaya River Basin, Louisiana. Transactions of the American Fisheries Society 128: 144-154. 
Sommer, T.R., Nobriga, M.L., Harrell, W.C., Batham, W., \& Kimmerer, W.J. 2001. Floodplain rearing of juvenile Chinook salmon: evidence of enhanced growth and survival. Canadian Journal of Fisheries and Aquatic Sciences 58: 325-333.

Sutton, T.M., Cyterski, M.J., Ney, J.J., \& Duval, M.C. 2004. Determination of factors influencing stomach content retention by striped bass captured using gillnets. Journal of Fish Biology 64: 903-910.

Thomaz, S.M., Bini, L.M., \& Bozelli, R.L. 2007. Floods increase similarity among aquatic habitats in river-floodplain systems. Hydrobiologia 579: 1-13.

Tockner, K., Malard, F., \& Ward, J.V. 2000. An extension of the flood pulse concept. Hydrological Processes 14: 2861-2883.

Vörösmarty, C.J. \& Sahagian, D. 2000. Anthropogenic disturbance of the terrestrial water cycle. BioScience 50(9): 753- 765.

Wheeler, A.P. \& Allen, M.S. 2003. Habitat and diet partitioning between shoal bass and largemouth bass in the Chipola River, Florida. Transactions of the American Fisheries Society 132: 438-449.

Winemiller, K.O. 1989. Ontogenetic diet shifts and resource partitioning among piscivorous fishes in the Venezuelan llanos. Environmental Biology of Fishes 26: 177-199.

Winemiller, K.O. \& Pianka, E.R. 1990. Organization in natural assemblages of dessert lizards and tropical fishes. Ecological Monographs 60 (1): 27-55. 
Winemiller, K.O. \& Kelso-Winemiller, L.C. 1994. Comparative ecology of the African pike, Hepsetus odoe, and tigerfish, Hydrocynus forskahlii, in the Zambezi River floodplain. Journal of Fish Biology 45: 211-225.

Winemiller, K.O. 1996. Factors driving temporal and spatial variation in aquatic floodplain food webs. In: G.A. Polis and K.O. Winemiller, eds. Food webs: integration of patterns and dynamics. New York, Chapman and Hall, pp. 1-22.

Winemiller, K.O., Tarim, S., Shormann, D., \& Cotner, J.B. 2000. Fish assemblage structure in relation to environmental variation among Brazos River oxbow lakes. Transactions of the American Fisheries Society 129: 451-468.

Winemiller, K.O. \& Jepsen, D.B. 2004. Migratory neotropical fish subsidize food webs of oligotrophic blackwater rivers. In: G.A. Polis, M.E. Power, and G.R. Huxel, eds. Food webs at the landscape level. Chicago, University of Chicago Press, pp. 115-132.

Zeug, S.C., Winemiller, K.O., \& Tarim, S. 2005. Response of Brazos River oxbow fish assemblages to patterns of hydrologic connectivity and environmental variability. Transactions of the American Fisheries Society 134: 1389-1399. 


\section{APPENDIX I}

Total volume of prey items for all gar species.

\begin{tabular}{|c|c|c|c|}
\hline & L. oculatus & L. osseus & A. spatula \\
\hline \multicolumn{4}{|l|}{$\underline{\text { Fishes }}$} \\
\hline \multicolumn{4}{|l|}{ Clupeidae } \\
\hline Dorosoma cepedianum & 492.0 & 480.0 & 66.0 \\
\hline Dorosoma petenense & 32.6 & 3.8 & - \\
\hline Dorosoma spp. & 22.2 & 18.9 & 3.0 \\
\hline \multicolumn{4}{|l|}{ Centrarchidae } \\
\hline Lepomis cyanellus & 39.0 & 15.0 & - \\
\hline Lepomis gulosus & 45.0 & 6.1 & - \\
\hline Lepomis humilis & 6.0 & - & - \\
\hline Lepomis megalotis & 53.0 & - & - \\
\hline Lepomis spp. & 69.5 & 4.0 & - \\
\hline Pomoxis annularis & 121.3 & 21.0 & 11.0 \\
\hline Centrarchidae & 24.3 & 63.6 & - \\
\hline \multicolumn{4}{|l|}{ Ictaluridae } \\
\hline Ameiurus melas & 114.4 & 2.1 & - \\
\hline Ameiurus natalis & - & 0.2 & - \\
\hline Ictalurus furcatus & - & 19.9 & 18.2 \\
\hline Ictalurus punctatus & 19.6 & 76.6 & 5.6 \\
\hline Ictalurus spp. & - & 14.2 & - \\
\hline Pylodictis olivaris & - & 20.0 & - \\
\hline Ictaluridae & 1.2 & 14.2 & - \\
\hline \multicolumn{4}{|l|}{ Cyprinidae } \\
\hline Cyprinella lutrensis & - & 6.9 & - \\
\hline
\end{tabular}




\begin{tabular}{|c|c|c|c|}
\hline Cyprinella venusta & - & 0.6 & - \\
\hline & L. oculatus & L. osseus & A. spatula \\
\hline Cyprinus carpio & 48.7 & - & - \\
\hline Notropis buchanani & - & 0.4 & - \\
\hline Notropis shumardi & - & 5.8 & - \\
\hline Pimephales vigilax & 0.8 & 3.1 & - \\
\hline Cyprinidae & - & 1.7 & - \\
\hline \multicolumn{4}{|l|}{ Catastomidae } \\
\hline Carpoides carpio & - & 48.8 & - \\
\hline Ictiobus bubalus & 14.8 & - & 148.0 \\
\hline \multicolumn{4}{|l|}{ Lepisosteidae } \\
\hline Lepisosteus spp. & - & - & 25.0 \\
\hline \multicolumn{4}{|l|}{ Percidae } \\
\hline Percina sciera & - & 2.7 & - \\
\hline Percina spp. & - & 1.1 & - \\
\hline Percidae & - & 0.3 & - \\
\hline \multicolumn{4}{|l|}{ Atherinopsidae } \\
\hline Menidia beryllina & - & 2.1 & - \\
\hline \multicolumn{4}{|l|}{ Poeciliidae } \\
\hline Gambusia affinis & 1.0 & - & - \\
\hline \multicolumn{4}{|l|}{$\underline{\text { Aquatic Invertebrates }}$} \\
\hline Cambaridae & 272.3 & 0.1 & - \\
\hline Ephemoroptera larva & - & 4.8 & - \\
\hline Macrobranchium & - & 1.7 & - \\
\hline Odonata Anisoptera larva & - & 0.6 & - \\
\hline Palaemonidae & 1.4 & 2.9 & - \\
\hline \multicolumn{4}{|l|}{ Terrestrial Invertebrates } \\
\hline Diptera Tipulidae & 0.1 & - & - \\
\hline
\end{tabular}




\begin{tabular}{lccc}
\hline & L. oculatus & L. osseus & A. spatula \\
\hline Orthoptera & 47.6 & 1.5 & - \\
Hymenoptera & - & 0.1 & - \\
Lepidoptera & - & 0.7 & - \\
Terrestrial Vertebrates & & & \\
Amphibia Anura & - & 2.8 & - \\
Rodentia & - & 0.5 & - \\
\hline
\end{tabular}




\section{APPENDIX II}

Sample dates by location for the dry year $(\mathrm{mm} / \mathrm{dd} / \mathrm{yy})$.

\begin{tabular}{lll}
\hline Brazos River & Big Bend & Moehlman's \\
\hline $06 / 02 / 03$ & $06 / 03 / 03$ & $06 / 09 / 03$ \\
$07 / 10 / 03$ & $07 / 22 / 03$ & $07 / 02 / 03$ \\
$08 / 15 / 03$ & $08 / 12 / 03$ & $08 / 06 / 03$ \\
$09 / 25 / 03$ & $09 / 28 / 03$ & $09 / 11 / 03$ \\
$10 / 29 / 03$ & $10 / 16 / 03$ & $10 / 11 / 03$ \\
$11 / 21 / 03$ & $11 / 19 / 03$ & $11 / 13 / 03$ \\
$12 / 18 / 03$ & $12 / 10 / 03$ & $12 / 05 / 03$ \\
$01 / 30 / 04$ & $01 / 15 / 04$ & $01 / 12 / 04$ \\
$02 / 27 / 04$ & $02 / 25 / 04$ & $02 / 06 / 04$ \\
$03 / 24 / 04$ & $03 / 16 / 04$ & $03 / 15 / 04$ \\
$04 / 01 / 04$ & $04 / 17 / 04$ & $04 / 08 / 04$ \\
$05 / 27 / 04$ & $05 / 20 / 04$ & $05 / 19 / 04$ \\
\hline
\end{tabular}




\section{APPENDIX III}

Sample dates by location for the wet year ( $\mathrm{mm} / \mathrm{dd} / \mathrm{yy})$.

\begin{tabular}{lll}
\hline Brazos River & Big Bend & Moehlman's \\
\hline $07 / 20 / 03$ & $06 / 28 / 03$ & $06 / 25 / 03$ \\
$08 / 17 / 03$ & $07 / 27 / 03$ & $07 / 14 / 03$ \\
$09 / 20 / 03$ & $08 / 28 / 03$ & $08 / 04 / 03$ \\
$11 / 07 / 03$ & $09 / 27 / 03$ & $09 / 13 / 03$ \\
$01 / 23 / 04$ & $10 / 24 / 03$ & $10 / 15 / 03$ \\
$04 / 18 / 04$ & $12 / 16 / 03$ & $12 / 05 / 03$ \\
$05 / 18 / 04$ & $01 / 29 / 04$ & $01 / 11 / 04$ \\
& $02 / 27 / 04$ & $02 / 13 / 04$ \\
& $03 / 17 / 04$ & $03 / 08 / 04$ \\
& $04 / 16 / 04$ & $04 / 04 / 04$ \\
& $05 / 26 / 04$ & $05 / 11 / 04$ \\
\hline
\end{tabular}




\section{VITA}

$\begin{array}{ll}\text { Name: } & \text { Clinton Ray Robertson } \\ \text { Address: } & \text { 7307 Roveen Trl } \\ & \text { San Antonio, TX 78244 }\end{array}$

Email Address: clinton_robertson@hotmail.com

Education: $\quad$ B.S., Wildlife and Fisheries Sciences, Texas A\&M University, 2004 M.S, Wildlife and Fisheries Sciences, Texas A\&M University, 2007 